\title{
Citrus Essential Oils (CEOs) and Their Applications in Food: An Overview
}

\author{
Himashree Bora ${ }^{1}$, Madhu Kamle ${ }^{1}$, Dipendra Kumar Mahato ${ }^{2}{ }^{\circledR}$, Pragya Tiwari ${ }^{3, *}$ and \\ Pradeep Kumar ${ }^{1, * \mathbb{D}}$ \\ 1 Department of Forestry, North Eastern Regional Institute of Science and Technology, Nirjuli 791109, India; \\ bora.heena12@gmail.com (H.B.); madhu.kamle18@gmail.com (M.K.) \\ 2 School of Exercise and Nutrition Sciences, Deakin University, 221 Burwood Hwy, Burwood, VIC 3125, \\ Australia; kumar.dipendra2@gmail.com \\ 3 Department of Biotechnology, Yeungnam University, Gyeongsan, Gyeongbuk 38541, Korea \\ * Correspondence: pragyamita02@gmail.com (P.T.); pkbiotech@gmail.com (P.K.); Tel.: +91-762-884-1479 (P.K.)
}

Received: 31 December 2019; Accepted: 2 March 2020; Published: 11 March 2020

\begin{abstract}
Citrus is a genus belonging to the Rutaceae family and includes important crops like orange, lemons, pummelos, grapefruits, limes, etc. Citrus essential oils (CEOs) consist of some major biologically active compounds like $\alpha$-/ $\beta$-pinene, sabinene, $\beta$-myrcene, $d$-limonene, linalool, $\alpha$-humulene, and $\alpha$-terpineol belonging to the monoterpenes, monoterpene aldehyde/alcohol, and sesquiterpenes group, respectively. These compounds possess several health beneficial properties like antioxidant, anti-inflammatory, anticancer, etc., in addition to antimicrobial properties, which have immense potential for food applications. Therefore, this review focused on the extraction, purification, and detection methods of CEOs along with their applications for food safety, packaging, and preservation. Further, the concerns of optimum dose and safe limits, their interaction effects with various food matrices and packaging materials, and possible allergic reactions associated with the use of CEOs in food applications were briefly discussed, which needs to be addressed in future research along with efficient, affordable, and "green" extraction methods to ensure CEOs as an ecofriendly, cost-effective, and natural alternative to synthetic chemical preservatives.
\end{abstract}

Keywords: Citrus essential oils (CEOs); antimicrobial; microencapsulation; food packaging and preservation

\section{Introduction}

The genus Citrus belongs to family Rutaceae, which includes about 140 genera and 1300 species. As a diverse tropical fruit, citrus combines species like Citrus sinensis (Orange), Citrus reticulata (Mandarin), Citrus aurantifolia (Limes), Citrus limon (Lemon), Citrus paradisi (Grapefruit), Citrus bergamia (Bergamot), Citrus junos (Yuzu), and Citrus japonica (Kumquat) [1,2]. The Citrus species originated from the Himalayan foothills of Northern India, Northern Myanmar, Southern China, and Southeast Asia $[3,4]$. Later, these fruits spread to the other parts of the world, becoming the world's highest value fruit crops [5]. Besides its use as a condiment, Citrus is also used as a part of many sweet delicacies in the European countries. Citrus is a major component of many savory dishes, such as pan-roasted chicken with orange-brandy sauce or pork tenderloin with blood oranges. These Citrus fruits have a very well-inscribed nutritional value, along with high levels of elemental bioactive compounds, viz., phenols, flavonoids, limonoids, essential oils (EOs), and vitamins, particularly vitamin $\mathrm{C}$ and carotenoids, which have numerous health benefits. Such components give this fruit a particular flavor and aroma, leading to a more balanced and tastier diet. Above all, Citrus is beneficial for curing and preventing many diseases [6,7]. Several studies showed the various beneficial activities of Citrus 
and its constituents like antioxidant, antimicrobial, anti-inflammatory, insecticidal properties. Citrus has also shown to be beneficial in reducing the chances of developing mental health diseases, like anxiolytic against anxiety and anticholinesterase against Alzheimer's, etc. [8]. Citrus fruits contain several important secondary metabolites, such as ascorbic acid, flavanones, phenolics, and pectin, which are recognized to have antioxidants properties beneficial for human health [9]. In addition, Citrus flavonoids are used against free radicals and possess anti-inflammatory properties and are used to reduces the brain and degenerative diseases.

Above all, the different plant parts (leaves, flowers, fruits, and peels) of Citrus are rich sources of EOs and other beneficial nutrients, such as vitamin B9, vitamin C, potassium, flavonoids, coumarins, pectin, and dietary fibers [10]. Citrus essential oils (CEOs) exhibit antioxidant, antidiabetic, insecticidal, antifungal, and antibacterial properties (Figure 1), which have important applications in the pharmaceutical, sanitary, cosmetic, agricultural, and food industries [11,12]. CEOs have a wide spectrum of applications ranging from applications in cosmetics, textiles, and pharmaceuticals to food formulations [13]. Due to their rich, pleasant, and refreshing aroma, CEOs are also used as room fresheners and disinfectants [2]. The pharmaceutical formulation prepared by adding $\beta$-cyclodextrin with orange EO (Citrus sinensis L.) and compounds of lemon (Citrus limon) helps reduce the chances of Alzheimer's disease [14].

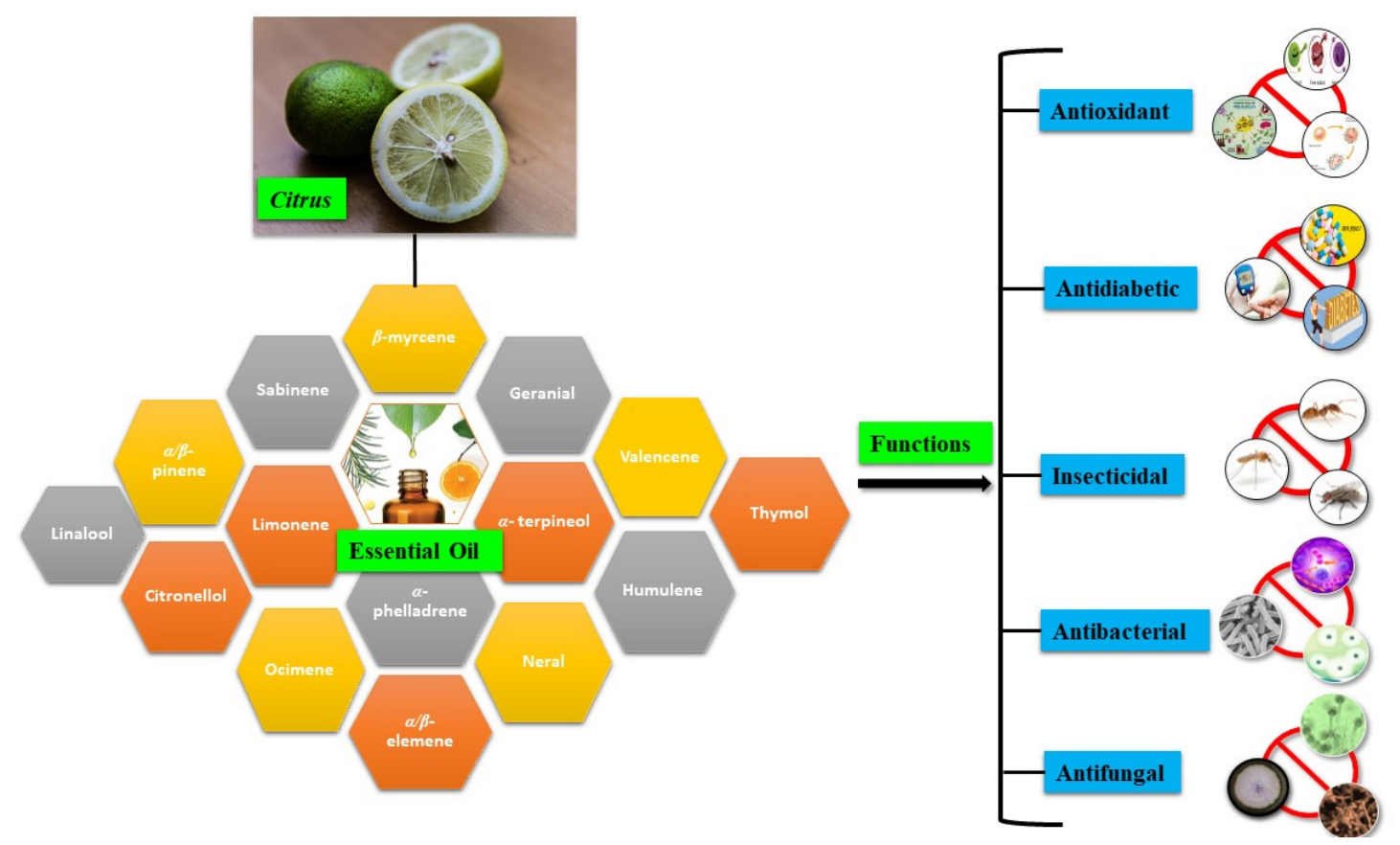

Figure 1. Citrus essential oils (CEOs) and their various functions.

Nowadays, food safety has become a fundamental concern for both consumers and food industries due to the increasing awareness and concerns regarding the effects of various food components on health. Natural and organic compounds have gained significant importance for their applications in foods, as they are beneficial to health with little or no side effects, cost-effective, and environmentally friendly compared to nonorganic synthetic compounds. Therefore, plant-derived natural antimycotics have become ideal alternatives to commercial synthetic chemical preservatives for improving food quality and safety [15-17]. In this regard, among the plant essential oils, CEOs have drawn more attention because of their broad-spectrum insecticidal, antibacterial, and antifungal properties along with their high yields, aromas, and flavors [18-21]. Furthermore, CEOs have wide applications in food formulations, packaging, and preservation to ensure food quality and safety [22]. Therefore, this review focused on the different extraction, purification, and detection methods of EOs from various Citrus species, their composition, and possible applications in food safety, packaging and preservation. 


\section{Extraction, Purification and Detection Methods for Citrus Essential Oils (CEOs)}

The extraction methods of various chemicals, along with EOs from Citrus and Citrus waste, are linked to energy consumption and $\mathrm{CO}_{2}$ emissions, which impact on the environment and cost. Therefore, proper and efficient extraction methods can achieve the maximum extraction, manage waste, and lead to the valorization of the byproduct $[23,24]$. The conventional methods of extraction viz., Soxhlet extraction, maceration, infusion, solid-liquid extraction (SLE), and liquid-liquid extraction (LLE), require greater extraction time and consume high energy, and sometimes may even require toxic solvents. In addition, the high operating temperature during the conventional extraction process may damage the heat-labile active compounds present in the extract [25]. Therefore, the current focus and requirements with extraction methods are shifting toward green extraction, which is ecofriendly with lower energy consumption and $\mathrm{CO}_{2}$ emissions [26]. For example, with liquid-liquid extraction (LLE), the use of biorenewable solvents based on various alkane diols have been assessed as ecofriendly substitutes to separate bioactive terpenoids from terpenes to obtain EOs during downstream processing [27]. Pourbafrani et al. [28] evaluated the emissions of greenhouse gas (GHG) associated with the biorefinery of Citrus processing waste (CPW), and found that replacing gasoline with ethanol (E85) in vehicle fueling and methane with natural gas, methane, for electricity production reduced GHG emissions by $134 \%$ and $77 \%$, respectively. The modern and nonconventional techniques may require high energy to run the extraction process, such as critical pressure, supercritical fluid (liquefied $\mathrm{CO}_{2}$ ), temperature, uninterrupted electricity supply, pumps, pressure containers, and highly sealed vessels, high maintenance, microwave, and ultrasound generating equipment. However, these methods require less solvent and provide a better quality extract, along with an enhanced extraction yield within a short extraction period [26]. Furthermore, modern extraction methods are still limited to laboratory research, and industrial applications are still to be realized.

Some of the green extraction methods include supercritical fluid extraction (SFE), steam explosion, ultrasound-assisted extraction (UAE), and microwave-assisted extraction (MAE) [29]. Among these, UAE and MAE are most widely used extraction methods for essential oils and other natural products from Citrus species (Table 1). These methods are easy and quick to operate with lower $\mathrm{CO}_{2}$ emissions and energy consumption [30-33]. Similarly, supercritical fluids are nontoxic, nonflammable, and operate at low and moderate temperatures and pressures without forming chemical residue [34]. Moreover, the combinations of UAE, along with some innovative techniques like the microwave technique, instant-controlled pressure drop technique (DIC), and SFE, were found to be the most promising hybrid techniques [31]. Besides this, microwave-assisted hydrodistillation (MAHD) has also been applied to extract EOs from wet citrus peel waste [35]. In addition, microwave hydrodiffusion and gravity (MHG) is superior to conventional methods [36], as this method is solvent-free with short extraction time and works under the effect of microwaves and the Earth's gravity [4,37]. Solvent-free extraction methods using microwave and ultrasound techniques have been successfully applied to extract EOs through hydrothermal processing [38]. Furthermore, cavitation-based extraction (CE) methods enhance the extraction quality and yield of the extract and reduce the extraction time [26]. Cavitation-based extraction (CE) methods include UAE, negative pressure cavitation (NPC) extraction, and hydrodynamic cavitation extraction (HCE). HCE is generally achieved by pumping a liquid through Venturi tubes or orifice plates which causes pressure gradient in the flow that leads to the generation, growth, and collapse of microbubbles [39]. Real-scale applications of HCE are applied to manage waste orange peels [40], as well as process other food waste [41]. HC-based processes have shown enhanced performance, yields and straightforward scalability [39,42]. In addition to this, a green and zero-energy consuming procedure based on solar energy using solar hydrodistillation (SSD) has been developed to extract essential oils [43]. 
Table 1. Extraction and detection methods of essential oils (EOs) from various Citrus species.

\begin{tabular}{|c|c|c|c|c|}
\hline Citrus Species & $\begin{array}{c}\text { Parts Used for } \\
\text { Extraction/Detection }\end{array}$ & Extraction Method & $\begin{array}{l}\text { Purification/Detection } \\
\text { Method }\end{array}$ & References \\
\hline $\begin{array}{l}\text { Citrus limon, C. aurantifolia, } C . \\
\text { sinensis, C. paradisi }\end{array}$ & Peels & $\begin{array}{c}\text { Microwave hydrodiffusion and } \\
\text { gravity }\end{array}$ & GC-MS & [36] \\
\hline $\begin{array}{l}\text { Citrus aurantium (Aurantii fructus } \\
\quad \text { immaturus, Aurantii fructus) }\end{array}$ & $\begin{array}{l}\text { Dried immature } \\
\text { fruits, dried ripe } \\
\text { fruits }\end{array}$ & Steam distillation (SD) & GC-FID, GC-MS & [44] \\
\hline Citrus reticulata & Peel, leaf & Hydrodistillation (HD) & GC-MS, NMR & [45] \\
\hline Citrus aurantium & Fruit cortex & Cold pressing & GC-MS & [46] \\
\hline Citrus aurantium & Bud & $\begin{array}{c}\text { Reflux extraction (RE), steam } \\
\text { distillation extraction (SDE), and } \\
\text { ultrasound-assisted extraction } \\
\text { (UAE) }\end{array}$ & GC-MS & [47] \\
\hline Citrus limon & Commercial oil & Brown oil extraction & $\begin{array}{l}\text { GC-FID/MS, FT-MIR, } \\
\text { H-NMR, } \\
\text { UHPLC-TOF-MS }\end{array}$ & [48] \\
\hline Citrus limon & Essential oil & Brown oil extraction & $\begin{array}{l}\text { GC-FID/MS, FT-MIR, } \\
\text { H-NMR, } \\
\text { UHPLC-TOF-MS }\end{array}$ & [49] \\
\hline Citrus aurantium & Flower & $\begin{array}{l}\text { HD and ultrasonic-assisted } \\
\text { headspace solid phase } \\
\text { micro-extraction (UA-HS-SPME) }\end{array}$ & GC-MS & [50] \\
\hline $\begin{array}{l}\text { Citrus limon, C. Sinensis, C. } \\
\text { reticulata, C. paradisi }\end{array}$ & Air dried peel & HD & GC-MS & [51] \\
\hline $\begin{array}{l}\text { Citrus sinensis, Citrus } x \text { paradisi, } \\
\text { Citrus deliciosa, Citrus limon, Citrus } \\
\text { aurantifolia }\end{array}$ & Essential oil & HD & $\begin{array}{l}\text { GC-FID, ATR-FTIR, } \\
\text { NIR-FT Raman }\end{array}$ & [52] \\
\hline Citrus aurantium & Peels & SD & HS-GC-MS & [53] \\
\hline $\begin{array}{c}\text { Citrus sinensis, Citrus limonum, } \\
\text { Citrus aurantium }\end{array}$ & Peels & HD & GC-MS & [54] \\
\hline Citrus aurantium & $\begin{array}{l}\text { Peel, flowers, and } \\
\text { leaves }\end{array}$ & HD & GC-FID, GC-MS & [55-58] \\
\hline Citrus aurantium & Flower & $\begin{array}{l}\text { SD, Liquid-liquid extractions with } \\
\text { n-hexane }\end{array}$ & $\begin{array}{l}\text { GC/FID, GC-MS, } \\
\text { GC/MS-LRI }\end{array}$ & {$[59,60]$} \\
\hline Citrus sinensis & Peels & $\begin{array}{l}\text { HD, Instant Controlled Pressure } \\
\text { Drop Technique (DIC), UAE, } \\
\text { Solvent Extraction (SE) }\end{array}$ & GC-MS & [61] \\
\hline Citrus limon & Fruits, peels & Cold pressing, HD & GC-MS & [62] \\
\hline $\begin{array}{l}\text { Citrus sinensis, Citrus limon, Citrus } \\
\text { reticulata, Citrus aurentium }\end{array}$ & Peels & $\begin{array}{l}\text { SD and microwave assisted steam } \\
\text { distillation (MASD) }\end{array}$ & GC-MS & {$[63,64]$} \\
\hline
\end{tabular}

The extracted compounds from Citrus processing waste contain a complex mixture of phytochemicals, which require further purification and refinement. The basic purification methods include column chromatography, High-Speed Counter-Current Chromatography (HSCC), High-Performance Liquid Chromatography (HPLC), and some solvent combinations, such as hexane: n-butanol, ethyl acetate: hexane, butanol: water, and chloroform: methanol, etc. [4]. After purification, the EOs present in the extract can be detected and quantified by several methods, such as Gas Chromatography-Mass Spectrometry (GC-MS), Gas Chromatography-Flame Ionization Detector (GC-FID), Nuclear Magnetic Resonance (NMR), Attenuated Total Reflection Fourier-Transform Infrared Spectroscopy (ATR-FTIR), Ultra-High Performance Liquid Chromatography Time-of-Flight Mass Spectrometry (UHPLC-TOF-MS), etc., as shown in Table 1.

\section{Composition of Citrus Essential Oils (CEOs)}

CEOs are a mixture of complex hydrocarbons and oxygenated derivatives of terpenoid and nonterpenoid origin consisting of functional groups such as aldehydes, alcohols, ketones, and other complex molecules, like esters and organic acids [65]. Chemically, normal edible oils and EOs are distinct from each other, as EOs are not esters of glycerides [66]. The composition of CEOs varies 
markedly based on variety, season, and geographic location, as well as the ripening stage of the fruit $[21,67,68]$. CEOs contain a wide variety of compounds, ranging from 20 to 60 compounds per CEO [69]. Of these, volatile compounds compose $85 \%-99 \%$, while the remaining composition $(1 \%-15 \%)$ consists of nonvolatile compounds. The volatile compounds contain a mixture of monoterpenes, sesquiterpenes, and sesquiterpenoids [70]. The major components are monoterpenes, which consist of two isoprene $\left(\mathrm{C}_{5} \mathrm{H}_{8}\right)$ units and account for around $97 \%$ of the CEOs, while alcohols, aldehydes, and esters represent $1.8 \%-2.2 \%$ of the CEOs [21,71]. Further, among these, limonene is the main component. The concentration of limonene varies between $32 \%$ and $98 \%$ depending on the variety, for example, $32 \%-45 \%$ in bergamot, $45 \%-76 \%$ in lemon and $68 \%-98 \%$ in sweet orange [71]. Figure 2 depicts the chemical structures of some important compounds of Citrus essential oils (CEOs).<smiles>C=C(C)C1CC=C(C)CC1</smiles><smiles>C=C1CCC2(C(C)C)CC1C2</smiles>

Sabinene<smiles>CC1=CCC2CC1CC2(C)C</smiles>

$\alpha$ - pinene<smiles>CC1=CCC(C(C)C)C=C1</smiles><smiles>C=C/C(C)=C\CC(C)C</smiles>

Ocimene<smiles>C=C[C@]1(C)CCC(C(=C)C)CC1C(=C)C</smiles>

$\beta$ - elemene $\alpha$ - phellandrene<smiles>C=C(C)C1CCC2=CCC[C@@H](C)[C@]2(C)C1</smiles>

Valencene<smiles>C=C1C2CCC(C2)C1(C)C</smiles>

Camphene<smiles>CC1=CCC2CC1C2(C)C</smiles>

$\beta$-pinene<smiles>C=CC(=C)CCC=C(C)C</smiles>

$\beta$-myrcene<smiles>C=C[C@]1(C)CCC(=C(C)C)C=C1C(C)C</smiles><smiles>C=C1CC/C=C(\C)CC[C@@H]2C[C@@H]1CC2(C)C</smiles>

Caryophylene

Figure 2. Cont. 
<smiles>CC1=CCCC(C)=CCC(C)(C)CC=C1</smiles>

Humulene<smiles>CC(C)=C1CC[C@@H](C)CC1O</smiles>

Citronellol<smiles>CC1=CCC(C(C)(C)O)CC1</smiles>

$\alpha-$ terpineol<smiles>CC(C)=CCCC(C)=CC=O</smiles>

Geranial<smiles>CC(C)=CCCC(C)=CCO</smiles>

Geraniol<smiles>CC(C)=CCC/C(C)=C\C=O</smiles>

Neral<smiles>C=C[C@](C)(O)CCC=C(C)C</smiles>

Linalool<smiles>CC(C)=CCC/C(C)=C\CO</smiles>

Nerol

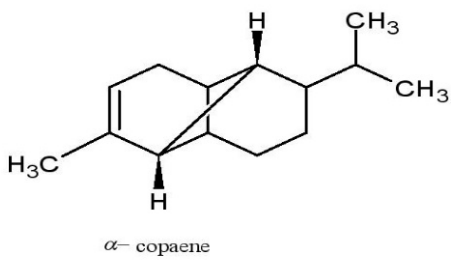<smiles>C=C1CCC2C(C)CCC(C(C)C)C2C1</smiles>

Figure 2. Chemical structures of some important compounds of Citrus essential oils (CEOs).

The EOs of $C$. medica in the fruit peel oil and leaf oil contain $39.37 \%$ of iso-limonene, $28.43 \%$ of erucylamide, $23.12 \%$ of citral, and $21.78 \%$ of limonene as vital components [9,72]. The EOs of Citrus sp. also contain an ample amount of monoterpene hydrocarbons, with limonene as the most substantial ingredient identified in the peels of C. microcarpa (94.0\%), C. grandis (81.6-96.9\%), and C. aurantifolia (39.3\%). On the other hand, the peel of $C$. hystrix has sabinene as the major component of about $36.4-48.5 \%$. Additionally, the leaves of C. hystrix, C. microcarpa, and C. grandis contain citronellal (61.7-72.5\%), linalool (56.5\%), and hedycaryol (19.0\%) as the core components, respectively [9]. In addition, 33 volatile compounds were identified in C. aurantifolia, among which $63.35 \%$ was $d$-limonene as the major constituent, along with $7.07 \%$ of 3,7-dimethyl-2,6-octadien-1-ol, $6.23 \%$ of geraniol, $4.35 \%$ of E-citral, $3.29 \%$ of Z-citral, and $2.25 \%$ of $\beta$-ocimene [73]. The EO from Kaffir lime (C. hystrix) was analyzed by gas chromatography-mass spectrometry (GC-MS), and it was found that $\beta$-pinene, sabinene, limonene, and citronellal were major constituents, with concentrations of $24.62 \%, 22.06 \%$, $19.29 \%$, and $10.58 \%$, respectively [74]. Some of the major compounds of different CEOs and their functions are summarized in Table 2. 
Table 2. Major compounds of different CEOs and functions.

\begin{tabular}{|c|c|c|c|c|c|}
\hline Compounds & Class & $\begin{array}{l}\text { Plant Parts } \\
\text { Analyzed }\end{array}$ & Citrus Species & Functions & References \\
\hline Limonene & Monoterpene & $\begin{array}{l}\text { Flower, peel, } \\
\text { leaf }\end{array}$ & $\begin{array}{l}\text { Mandarin, orange, } \\
\text { pummelo, lemon }\end{array}$ & $\begin{array}{c}\text { Anti-inflammatory, } \\
\text { antidiabetic, anticancer, } \\
\text { antioxidant, lipid lowering }\end{array}$ & [75-77] \\
\hline$\alpha$-pinene & Monoterpene & $\begin{array}{l}\text { Flower, peel, } \\
\text { leaf }\end{array}$ & $\begin{array}{l}\text { Mandarin, orange, } \\
\text { pummelo, lemon }\end{array}$ & Antimicrobial & {$[76,78,79]$} \\
\hline Camphene & Monoterpene & Peel, leaf & $\begin{array}{l}\text { Lemon, lime, } \\
\text { pummelo, mandarin, } \\
\text { sour orange }\end{array}$ & Lipid lowering & {$[80,81]$} \\
\hline$\beta$-pinene & Monoterpene & $\begin{array}{l}\text { Flower, peel, } \\
\text { leaf }\end{array}$ & $\begin{array}{l}\text { Pummelo, mandarin, } \\
\text { orange, lemon }\end{array}$ & Antifungal & {$[78,82]$} \\
\hline Sabinene & Monoterpene & $\begin{array}{l}\text { Flower, peel, } \\
\text { leaf }\end{array}$ & $\begin{array}{l}\text { Pummelo, mandarin, } \\
\text { orange, lemon }\end{array}$ & Antifungal & {$[75,76,78]$} \\
\hline$\alpha$-phellandrene & Monoterpene & Peel, leaf & Mandarin, orange & Insecticidal activity & {$[75,83]$} \\
\hline$\beta$-myrcene & Monoterpene & Flower, leaf & $\begin{array}{l}\text { Pummelo, mandarin, } \\
\text { orange, lemon }\end{array}$ & $\begin{array}{c}\text { Antifungal, } \\
\text { embryofoetotoxicity }\end{array}$ & {$[76,78,84]$} \\
\hline$(\mathrm{E}) /(\mathrm{Z})$-ocimene & Monoterpene & $\begin{array}{l}\text { Flower, peel, } \\
\text { leaf }\end{array}$ & $\begin{array}{l}\text { Pummelo, mandarin, } \\
\text { orange, lemon }\end{array}$ & $\begin{array}{c}\text { Antiviral, antifungal, } \\
\text { anti-inflammatory, } \\
\text { antibacterial, anti-oxidative, } \\
\text { antiseptic effects }\end{array}$ & {$[75,76,78]$} \\
\hline Valencene & Sesquiterpenes & Fruit, peel & $\begin{array}{l}\text { Blood orange, Citrus } \\
\text { limon } \mathrm{L}\end{array}$ & $\begin{array}{l}\text { Anti-inflammatory, } \\
\text { anti-allergic effects }\end{array}$ & [71] \\
\hline$\beta$-/ $/$-elemene & Sesquiterpenes & $\begin{array}{l}\text { Flower, peel, } \\
\text { leaf }\end{array}$ & $\begin{array}{l}\text { Pummelo, orange, } \\
\text { lemon, grapefruit }\end{array}$ & Anti-glioblastoma, anticancer & {$[76,78,85]$} \\
\hline$\alpha-/ \beta$-copaene & Sesquiterpenes & Flower, peel & $\begin{array}{l}\text { Pummelo, mandarin, } \\
\text { orange, lemon }\end{array}$ & Attractant for male fruit flies & {$[76,78,86]$} \\
\hline (E)-/ $\beta$-caryophyllene & Sesquiterpenes & $\begin{array}{l}\text { Flower, peel, } \\
\text { leaf }\end{array}$ & $\begin{array}{l}\text { Pummelo, mandarin, } \\
\text { orange, lemon }\end{array}$ & $\begin{array}{c}\text { Antimicrobial, } \\
\text { anti-inflammatory, antibiotic, } \\
\text { anticancer, antioxidant }\end{array}$ & {$[76,78,87]$} \\
\hline$\alpha$-humulene & Sesquiterpenes & Peel & $\begin{array}{l}\text { Pummelo, mandarin, } \\
\text { orange, lemon }\end{array}$ & Anticancer & {$[75,76,87]$} \\
\hline Geranial & $\begin{array}{l}\text { Sesquiterpene } \\
\text { aldehyde }\end{array}$ & Flower, leaf & $\begin{array}{l}\text { Mandarin, orange, } \\
\text { lemon }\end{array}$ & Antifungal & {$[76,78,88]$} \\
\hline Geraniol & Terpene alcohol & Flower, leaf & $\begin{array}{l}\text { Pummelo, mandarin, } \\
\text { orange, lemon }\end{array}$ & $\begin{array}{c}\text { Antimicrobial, } \\
\text { anti-inflammatory, anticancer, } \\
\text { antioxidant }\end{array}$ & {$[76,78,89]$} \\
\hline$\alpha$-/ $\beta$-citronellol & $\begin{array}{l}\text { Monoterpene } \\
\text { alcohol }\end{array}$ & Flower, leaf & $\begin{array}{l}\text { Orange, lemon, } \\
\text { mandarin }\end{array}$ & $\begin{array}{l}\text { Anti-inflammatory, increase } \\
\text { perspiration }\end{array}$ & {$[76,78]$} \\
\hline Neral & $\begin{array}{l}\text { Monoterpene } \\
\text { aldehyde }\end{array}$ & Leaf, peel & Lemon & Antifungal & {$[76,88]$} \\
\hline Nerol & $\begin{array}{c}\text { Monoterpene } \\
\text { alcohol }\end{array}$ & Flower, leaf & $\begin{array}{l}\text { Orange, lemon, } \\
\text { mandarin, pummelo }\end{array}$ & Antimicrobial & {$[76,78,90]$} \\
\hline$\alpha$-terpineol & $\begin{array}{l}\text { Monoterpene } \\
\text { alcohol }\end{array}$ & Leaf, peel & Lemon & Antifungal & {$[76,82]$} \\
\hline Linalool & $\begin{array}{l}\text { Monoterpene } \\
\text { alcohol }\end{array}$ & $\begin{array}{l}\text { Flower, peel, } \\
\text { leaf }\end{array}$ & $\begin{array}{l}\text { Orange, lemon, } \\
\text { mandarin, pummelo }\end{array}$ & Antidiabetic & {$[75,76,78,91]$} \\
\hline Thymol & $\begin{array}{l}\text { Monoterpene } \\
\text { phenol }\end{array}$ & Flower & Orange, mandarin, & Antimicrobial & {$[78,92]$} \\
\hline
\end{tabular}

\section{Applications of CEO}

CEOs have a wide range of applications from cosmetics to pharmaceuticals and food formulations and packaging. However, this study focused on the applications of CEOs concerning food safety, packaging, and preservation.

\subsection{Applications of CEO for Food Safety}

Commercial antimicrobial agents are used to manage food contamination and deterioration. However, due to growing health concerns, attention has been shifted to natural antimicrobials, such as plant-based essential oils. EOs and their components possess antimicrobial and food preservative 
properties against a broad spectrum of pathogens [93-98]. In line with this, CEOs and their insecticidal, antibacterial, and antifungal properties for food safety aspects are discussed briefly.

\subsubsection{CEO as an Insecticidal Agent}

Conventional chemical pesticides are effective for controlling various harmful insects. However, the continued and uncontrolled use of pesticides can lead to adaptation of such insects, leading to resistance against pesticides $[99,100]$. Chemical-based pesticides always have a perishable impact on the environment, which threatens the entire food web and indirectly threatens the nontargeted organisms [101,102]. This complication has resulted in search of an alternative, environmentally friendly, nonhazardous plant-based option [74]. In this context, Citrus plants are known for their medicinal properties and are candidates to replace conventional chemical pesticides. Therefore, instead of a synthetic and inorganic chemical derived insecticide, bioactive compounds of Citrus, especially CEOs, can be used as a substitute $[103,104]$.

Many studies have shown that EOs of Citrus sp. possess remarkable insecticidal activity. EOs from the peel of Citrus sp. C. maxima Merr. (pummelo), C. reticulata Blanco, C. suncris Linn, C. sinensis Linn, and C. hystrix were tested against the female cattle tick (Boophilus microplus), where the EO of C. reticulata showed highest acaricidal activity [105]. Similarly, the EO of sweet orange (Citrus sinensis) was tested against larvae and pupae of housefly (Musa domestica), and it was observed that the lethal concentration $\left(\mathrm{LC}_{50}\right)$ of the EO against larvae varied between $3.93-0.71 \mu \mathrm{L} / \mathrm{cm}^{2}$ and $71.2-52.6$ $\mu \mathrm{L} / \mathrm{L}$, respectively, during contact toxicity and fumigation bioassays. On the other hand, the rate of percentage inhibition of the oil varied between $27.3 \%-72.7 \%$ and $46.4 \%-100 \%$, respectively, for contact toxicity and fumigation assay against housefly pupae [101]. In addition, EOs from plants like C. bergamia (bergamot), Cymbopogon martini (palmarosa grass), Vetiveria zizanioides (vetiver grass), and Juniperus virginiana (red cedar) showed insecticidal property against the housefly (Musa domestica) [106].

Furthermore, citrus essential oil-nanoparticles (CEO-NPs) nanoformulation was tested against an invasive tomato borer, Tuta absoluta. The assay showed an impressive result for the insecticidal properties of the compounds tested. The higher mortality was observed for EO emulsion on eggs and larvae through contact toxicity assay and by EO-NPs on larvae through ingestion toxicity [107]. Besides this, analysis by fumigant toxicity, as well as the insecticidal mechanism through acetylcholinesterase (AChE) and $\mathrm{Na} / \mathrm{K}$-ATPase activities of EO from the peel of orange against Tribolium confusum, Callosobruchus maculatus, and Sitophylus oryzae, were investigated by Oboh et al. [108]. The results showed detrimental effects against these insects. The percentage mortality increased with an increase in concentration and exposure time, while $\mathrm{LC}_{50}$ decreased with exposure time. At the highest concentration of $150 \mu \mathrm{L} / \mathrm{L}$, $100 \%$ mortality was observed in T. confusum with $\mathrm{LC}_{50}$ values of $38.90 \mu \mathrm{L} / \mathrm{L}, 26.92 \mu \mathrm{L} / \mathrm{L}$, and $14.45 \mu \mathrm{L} / \mathrm{L}$ after $24 \mathrm{~h}, 48 \mathrm{~h}$, and $72 \mathrm{~h}$ of treatment, respectively. An increase in C. maculatus insecticidal activity was observed for high doses 100-150 $\mu \mathrm{L} / \mathrm{L}$ with $100 \%$ mortality and $\mathrm{LC}_{50}$ values of $17.78 \mu \mathrm{L} / \mathrm{L}$ and $10.00 \mu \mathrm{L} / \mathrm{L}$ after $48 \mathrm{~h}$ and $72 \mathrm{~h}$, respectively. Similarly, for S. oryzae, the insecticidal activity increased after $72 \mathrm{~h}$ of treatment with an $\mathrm{LC}_{50}$ value of $29.51 \mu \mathrm{L} / \mathrm{L}$. Finally, it was revealed that for T. confusum and C. maculatus, EO exhibited higher insecticidal activity as compared to S. oryzae. On the other hand, studies on biochemical analysis revealed that the bioactivity of EO can hinder the mechanism of acetylcholinesterase $(\mathrm{AChE})$ and $\mathrm{Na} / \mathrm{K}$-ATPase. Thus, the entire experiment stipulates the positive role of orange peel $\mathrm{EO}$ and its effectiveness in controlling T. confusum, C. maculatus and S. oryzae [108]. Sanei-Dehkordi et al. [109] further showed that the EO from the peel of Citrus aurantium and Citrus paradisi had larvicidal activity against Anopheles stephensi (a mosquito vector), with $\mathrm{LC}_{50}$ values of 31.20 ppm and 35.71 ppm, respectively.

\subsection{2. $\mathrm{CEO}$ as an Antibacterial Agent}

In the current scenario, the state of antibiotics against human pathogenic diseases is becoming very substandard because of the increasing resistance of microorganisms toward antimicrobial drugs. It is very challenging for the researcher to come up with an improvised formulation against such pathogens 
which can give a long-lasting solution [110]. Medicinal plants rich in phytochemical compounds are often found to have antibacterial and antifungal properties apart from commercial insecticides and have negligible side effects [111]. Researches conducted for antibacterial activity from CEOs have given a positive response among plant-based antibiotic discoveries.

Mehmood et al. [112] analyzed the antimicrobial activity of peel EO of ripened and unripened C. limon against four human pathogenic bacteria viz., Escherichia coli, Bacillus subtilis, Salmonella typhimurium, and Staphylococcus aureus. Zone inhibition studies were performed using disc diffusion assay, and it was found that EO from ripened peel had the highest antibacterial activity. Chen et al. [113] determined the antibacterial activity of $C$. maxima $E O$ against human pathogenic bacteria $(E$. coli, B. subtilis, S. aureus, P. aeruginosa, B. licheniformis, and B. altitudinis) using minimum inhibition concentration (MIC) ranging from $475-1104 \mu \mathrm{g} / \mathrm{mL}$, where the EO showed inhibition against all the strains. Further, the antibacterial activity of EO from $C$. aurantium against eight pathogenic bacteria $(S$. epidermidis, P. aeruginosa, S. aureus, M. luteus, E. coli, S. typhimerium, L. monocytogenese, and E. faecium) showed maximum inhibition zone ranging from 6-16 $\mathrm{mm}$ for all the strains at a concentration of $7 \mu \mathrm{L}$ per disc [114]. Similarly, the peel EO of Citrus reticulata, Citrus sinensis, and Citrus $\times$ sinensis were subjected for antibacterial analysis against four pathogenic bacteria, two Gram +ve (S. aureus and B. subtilis) and two Gram -ve bacteria (E. coli and P. multocida), using disc diffusion assay. The highest zone of inhibition were observed as $26.16 \pm 0.28 \mathrm{~mm}$ for B. subtilis, $25.50 \pm 0.50 \mathrm{~mm}$ for $S$. aureus, $37.42 \pm 0.38 \mathrm{~mm}$ for E. coli, and $35.50 \pm 0.50 \mathrm{~mm}$ for P. multocida for the EO of C. reticulata [115]. Further, it has been observed that EO works in synergy with other biomolecules. For example, a composite of commercial citrus essential oil and chitosan (CEO-CS) was used as perseverative for Pneumatophorus japonicus against two test bacteria E. coli and L. monocytogenes. The antimicrobial activity was evaluated by the oxford cup method, where the inhibition zone for chitosan (CS) was $12.24 \pm 1.03 \mathrm{~mm}$ for E. coli and $13.35 \pm 0.79 \mathrm{~mm}$ for L. monocytogenes. On the other hand, the CEO-CS composite showed an enhanced efficacy with a diameter of $17.23 \pm 1.29 \mathrm{~mm}$ for E. coli and $19.19 \pm$ $1.27 \mathrm{~mm}$ for L. monocytogenes [116]. The antibacterial properties of CEOs and their components are summarized in Table 3.

\subsubsection{CEO as an Antifungal Agent}

Fungal growth is one of the leading causes of food spoilage and huge economic losses [126]. Molds can colonize and spoil a wide array of foods ranging from fresh fruits and vegetables to grains and processed foods, leading to quantitative and qualitative losses $[18,126,127]$. Therefore, CEOs can be employed as a natural antifungal agent to minimize the fungal growth and contamination and extend the shelf life of various foods. CEOs have a broad-spectrum fungicidal activity (Table 4). The $\mathrm{EO}$ of $C$. sinensis was found to be active against Aspergillus niger [128]. Fungicidal activity in the agar medium was evaluated with EO ranging from $0.1-3.0 \mu \mathrm{g} / \mathrm{mL}$, and results showed that the highest inhibition was found at $3.0 \mu \mathrm{g} / \mathrm{mL}$ [128]. Lemon EO (Citrus limon) was used to control the fungal plant pathogens attacking grapevines, namely Eutypa sp., Botryospaeria dothidea, and Fomitiporia mediterranea. The antifungal activity was observed for EO against all the three pathogenic fungi with the highest activity (82\% inhibition) against Eutypa sp. and the lowest (33.1\% inhibition) against $F$. mediterranea [129]. Similarly, EO from $C$. reticulata was tested for the antifungal activity against five plants pathogenic fungi viz., A. alternata, R. solani, C. lunata, F. oxysporum, and H. oryzae. The activity was evaluated by the poisoned food technique and the volatile activity assay. The EO gave better results in volatile activity assay, where MIC was $0.2 \mathrm{~mL} / 100 \mathrm{~mL}$ for A. alternata, R. solani, and C. lunata, while in poisoned food technique, MIC was found to be $>0.2 \mathrm{~mL} / 100 \mathrm{~mL}$ for F. oxysporum and H. oryzae. Besides this, spore formation was also completely inhibited at $0.2 \mathrm{~mL} / 100 \mathrm{~mL}$ except for C. lunata and H. oryzae [130]. Furthermore, CEOs from four cultivars of Citrus namely C. aurantium, C. limon, C. reticulata, and C. sinensis were tested against Candida albicans and Aspergillus flavus using disc diffusion assay. It was found that antifungal activity was highest, with $\mathrm{EO}$ of $C$. reticulata where inhibition zone 
(IZ) was $26.1 \pm 1.20 \mathrm{~mm}$ and MIC of $1 \mathrm{mg} / \mathrm{mL}$ for C. albicans, while IZ of $43.1 \pm 1.67 \mathrm{~mm}$ and MIC of $0.25 \mathrm{mg} / \mathrm{mL}$ for A. flavus [131].

Table 3. Antibacterial properties of CEOs and their components.

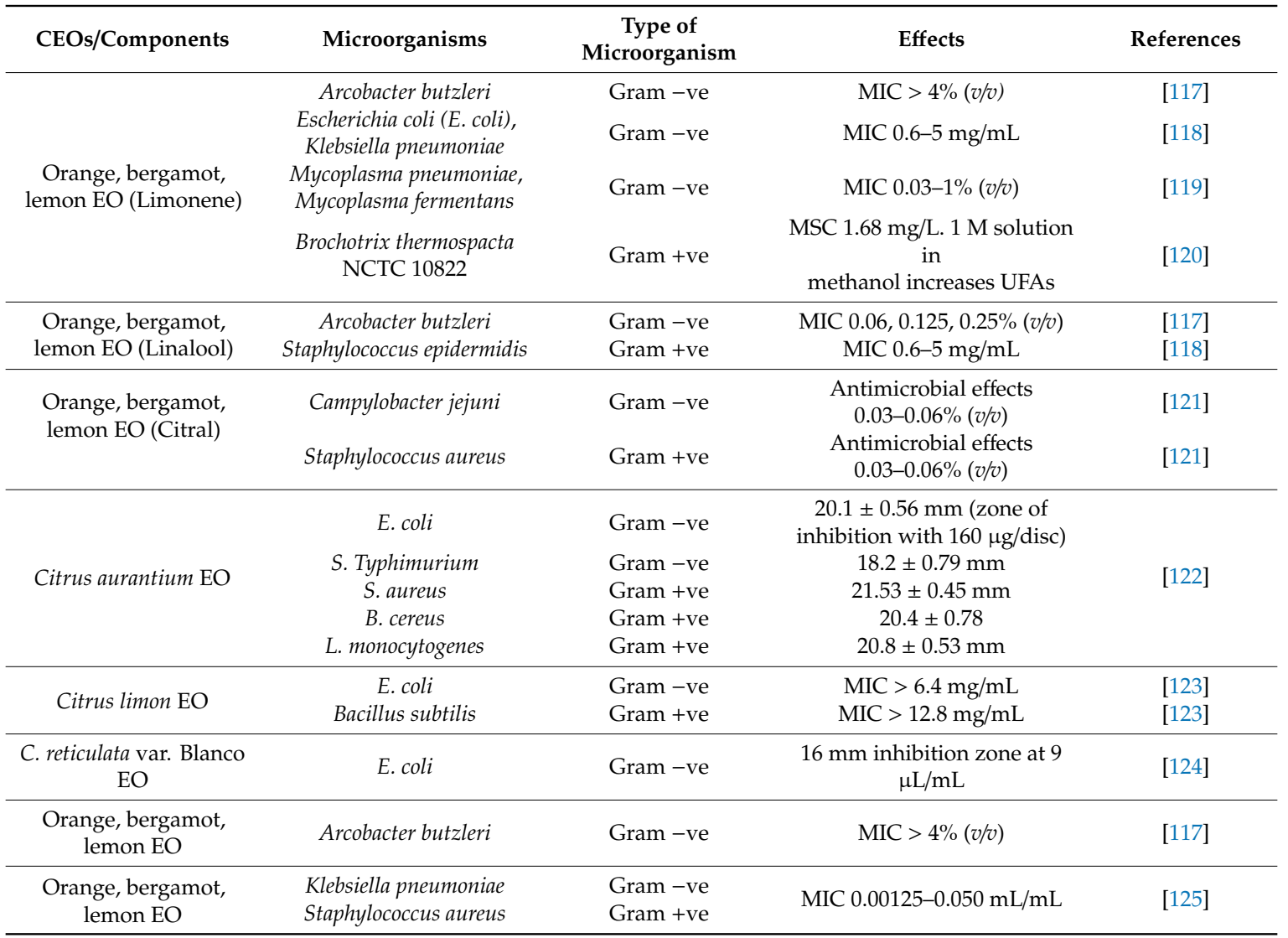

Table 4. Antifungal properties of CEOs and their components.

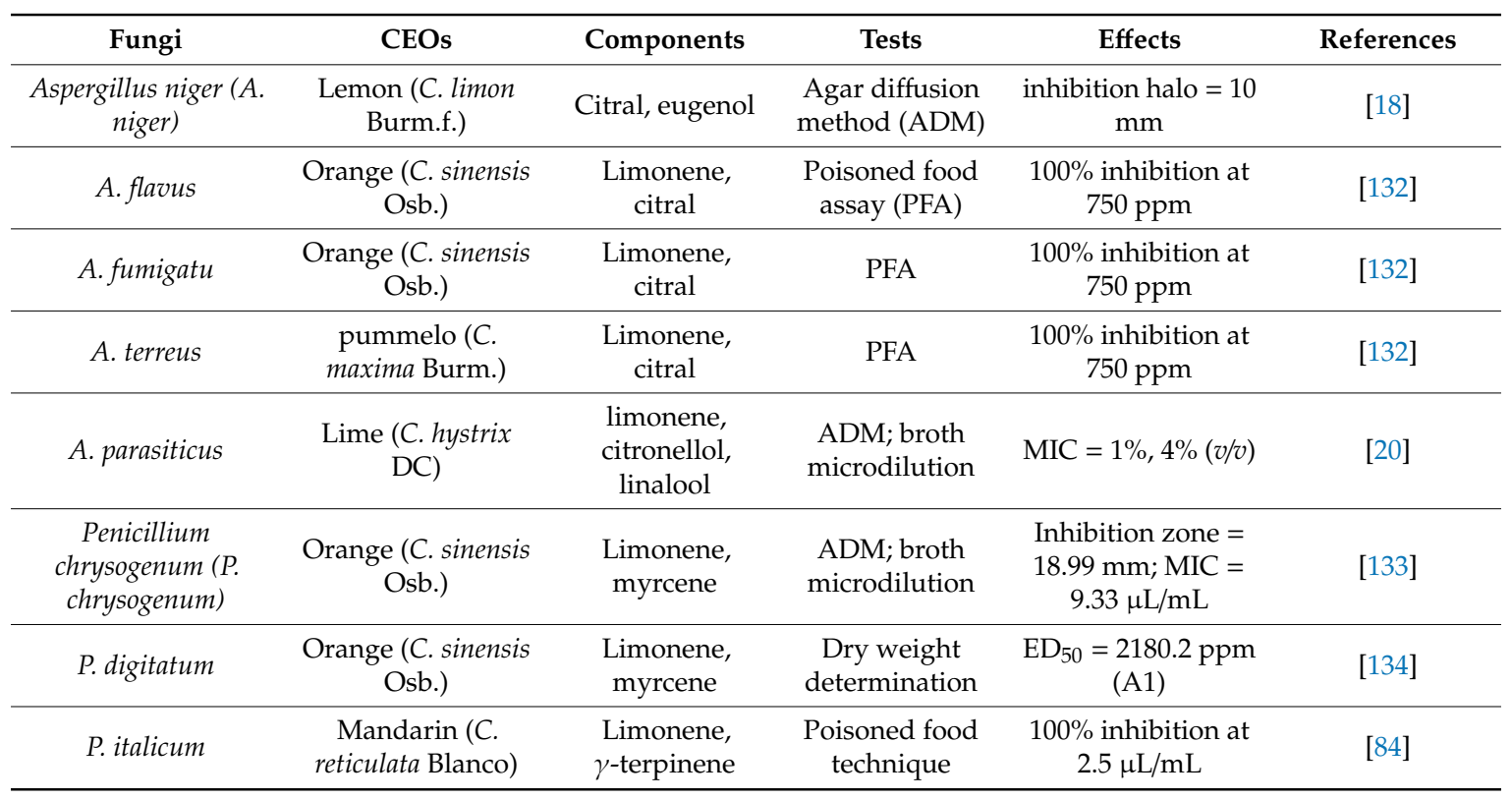


Table 4. Cont.

\begin{tabular}{|c|c|c|c|c|c|}
\hline Fungi & CEOs & Components & Tests & Effects & References \\
\hline Alternaria alternata & $\begin{array}{l}\text { Mandarin }(C . \\
\text { reticulata Blanco) }\end{array}$ & $\begin{array}{c}\text { Limonene, } \\
\text { geranial }\end{array}$ & PFA; VAA & $\mathrm{MIC}=0.2 \%(v / v)$ & [130] \\
\hline $\begin{array}{l}\text { Rhizoctonia solani, } \\
\text { Curoularia lunata }\end{array}$ & $\begin{array}{l}\text { Mandarin }(C . \\
\text { reticulata Blanco) }\end{array}$ & $\begin{array}{c}\text { Limonene, } \\
\text { geranial }\end{array}$ & PFA; VAA & $\mathrm{MIC}=0.2 \%(v / v)$ & [130] \\
\hline $\begin{array}{l}\text { Botryodiplodia } \\
\text { theobromae, } \\
\text { Myrothecium } \\
\text { roridum }\end{array}$ & $\begin{array}{c}\text { Orange (C. sinensis } \\
\text { Osb.) }\end{array}$ & $\begin{array}{l}\text { Limonene, } \\
\text { linalool }\end{array}$ & PFA; VAA & $\begin{array}{c}\mathrm{MIC}=600 \mathrm{ppm} / \\
700 \mathrm{ppm}(\mathrm{VA})\end{array}$ & [136] \\
\hline Mucor hiemalis & $\begin{array}{c}\text { Orange (C. sinensis } \\
\text { Osb.) }\end{array}$ & $\begin{array}{l}\text { Limonene, } \\
\text { myrcene }\end{array}$ & ADM & $\begin{array}{l}36.5 \% \text { inhibition at } \\
2000 \mathrm{ppm}\end{array}$ & [135] \\
\hline $\begin{array}{c}\text { Helminthosporium } \\
\text { oryzae, Trichoderma } \\
\text { viride }\end{array}$ & $\begin{array}{l}\text { Orange (C. sinensis } \\
\text { Osb.), pummelo (C. } \\
\text { maxima Burm.) }\end{array}$ & $\begin{array}{l}\text { Limonene, } \\
\text { citral }\end{array}$ & PFA & $\begin{array}{c}100 \% \text { inhibition at } \\
750 \mathrm{ppm}\end{array}$ & [132] \\
\hline
\end{tabular}

\subsection{Applications of CEO for Food Packaging and Preservation}

Food packaging is designed to serve the purpose of protecting the food from environmental conditions of humidity, light, and temperature, as well as others factors like dust, microorganisms, shocks, and vibrations [137,138], thereby enhancing the quality and shelf-life of foods [139]. The critical aspects of food packaging lie with the preservation of the original organoleptic properties of foods. In this regard, active packaging has emerged to extend the shelf-life of foods. Active packaging can contain intended components to be released into the foods to enhance the organoleptic properties and shelf-life, as well as to ensure food safety [140-143].

\subsubsection{CEO-Based Edible Films and Coatings}

Recent trends in packaging show the use of biodegradable materials to reduce the load on the environment, as they are ecofriendly and nontoxic with desirable physicochemical properties over their synthetic counterparts [144]. Proteins, lipids, and polysaccharides are usually utilized to produce bio-based packaging materials for food applications [145]. Among these, proteins are extensively used because of their abundance and better film-forming property. The protein-based films exhibit excellent barrier properties for gases (e.g., $\mathrm{O}_{2}$ and $\mathrm{CO}_{2}$ ), as well as for volatile compounds [146]. Edible films and coatings are forms of active packaging for food preservation and shelf-life extension. These are made up of polysaccharides, proteins, and lipids that act as barriers to moisture, carbon dioxide, oxygen, and vapor [147]. Further, the edible films and coatings with antioxidant and antimicrobial properties can prevent food spoilage by microorganisms $[67,69,148-150]$. As CEOs are generally recognized as safe (GRAS) by the U.S. Food and Drug Administration (USFDA) [151], they can be used with edible films and coatings to their limits that they provide maximum protective effects without much impact on the sensory and organoleptic properties of the food [152].

Therefore, CEOs possess immense potential for their applications in food safety, packaging, and preservation. The addition of CEOs into gelatin films provided antimicrobial activity along with enhanced physicochemical properties. The incorporation of EO with chitosan, i.e., chitosan-Eos, further 
enhanced the properties of chitosan. The CS-EO composite edible coatings were able to extend the shelf-life of sweet pepper [153] and table grapes [154]. Further, modified chitosan coatings containing limonene (and/or EO) showed effective activity in cold-stored strawberries [155]. In addition to this, chitosan-lemon EO composite coatings exhibited antimicrobial activity and enhanced the postharvest quality of cold-stored strawberries [156]. Alparslan et al. [157] studied the effect of edible gelatin-coating enriched with orange leaf EO on the shelf-life of cold-stored pink shrimp. The addition of $2 \%$ orange leaf EO to the gelatin solution was found to extend the shelf-life of shrimps by 10 days more as compared to the noncoated control samples. Later, Alparslan and Baygar [158] studied the effect of chitosan films containing orange peel EO on the shelf-life of pink shrimp. Chitosan with $2 \%$ orange peel EO inhibited the lipid oxidation and microbial growth, thereby extending the shelf-life of shrimps by nearly eight days compared to the noncoated shrimps. Further, Randazzo et al. [159] evaluated the antimicrobial activity of eight EOs extracted from the fruit peel of the lemon, orange, and mandarin against 76 strains of Listeria monocytogenes. The antibacterial effect of the EOs showed the highest inhibition when incorporated into chitosan- or methylcellulose-based biodegradable films. Therefore, chitosan films with lemon EOs can be used to control L. monocytogenes in refrigerated conditions. Similarly, the effects of lemon, orange, and grapefruit Eos added to sodium alginate edible coating was studied on the shelf-life of fresh-cut Jintao kiwifruits by Chiabrando and Giacalone [160]. The coating with these EOs significantly inhibited the growth of yeast and mold. On the other hand, the raspberries coated with alginate and lemon EO $(0.2 \%)$ or orange EO $(0.1 \%)$ inhibited the growth of bacteria, yeast, and mold and showed improved post-harvest quality [161]. Also, the starch films containing orange EO were found to be effective against L. monocytogenes and S. aureus [162]. Furthermore, the effects of the nanoclay film (prepared using a solution of sodium alginate and solid sodium gelatin) with $0.4 \%$ and $0.6 \%$ of citrus essential oil were effective in controlling Listeria monocytogenes, Vibrio parahaemolyticus, Streptococcus iniae, and Salmonella typhi in fishery products [163].

\subsubsection{CEO-Based Microencapsulation}

Microencapsulation is a technique of protecting natural ingredients, polyphenols, volatile compounds, EOs, enzymes, and even bacteria against nutritional losses and from environmental factors by encapsulating using an appropriate coating material [164]. The active component inside the microcapsule is variably known as the core, encapsulant, internal phase, payload phase, or fill, whereas the coating wall is referred as the carrier material, wall material, encapsulating agent, membrane shell, external phase, or matrix [165]. The microcapsules' size range between 3-800 mm in diameter, and $10 \%-90 \%$ of their core material should remain within the capsule for a specific period before its release in foods or the target site in a controlled manner [166]. Microencapsulation can be performed by coacervation or by a drying process. The coacervation can be either in the aqueous phase (i.e., encapsulation of water-insoluble/hydrophobic core materials) or in the organic phase (i.e., encapsulation of water-soluble compounds). On the other hand, the drying process can be achieved either by fluidized-bed coating, spray-drying, spray-bed-drying, or freeze-drying (lyophilization) [166,167].

The encapsulation of EOs as core material ensures their stability by protecting direct reaction with food matrices. Therefore, the selection of appropriate coating materials, as well as the encapsulation technique, is crucial to maximizing the incorporation and retention of the functional components within the encapsulation matrix. For example, maltodextrin is a common and low-cost polysaccharide with neutral taste and aroma used as an efficient coating material for rosemary EO [168]. Further, the encapsulated phenolic compounds present in CEOs can protect foods like meat, fish, and processed products from microbial spoilage, as well as from the lipid oxidative degradation. Raksa et al. [169] prepared the kaffir lime peel EO microcapsules using a complex coacervation method with gelatin and gum arabic as wall materials and studied their antibacterial activity. The microcapsules containing the EO showed antibacterial activity against Staphylococcus aureus. Further, de Araújo et al. [170] performed microencapsulation of sweet orange EO (SOEO) using maltodextrin and gelatin as wall materials in 
different ratios. The SOEO microcapsules showed antibacterial and antioxidant properties, thereby suggesting microencapsulated CEOs to be of great importance for the food industries. The mechanism of antimicrobial action of CEOs occurs by the controlled release of the lipolytic components in CEOs and disruption of the cell membrane structure of the microbes. In addition to this, CEOs also add taste and flavor to foods [166].

\subsubsection{CEO-Based Nanoemulsion}

The size of CEO-based nanoemulsion droplets ranges between 20-200 nm. Nanoemulsion droplets have a larger surface area and have more effective antimicrobial actions compared to microemulsion due to the larger number of droplets. However, the type and composition of feed material have to be optimized in order to obtain kinetically stable nanoemulsions [171]. Recently, hydrodynamic cavitation has emerged as a low-cost, effective, efficient, and scalable method and technology for extracting and nanoemulsifying CEOs, which also takes advantage of the copresence of pectin in citrus peels [40]. CEOs are cost-effective, environmentally friendly, and relatively nontoxic materials of interest with huge potential bioactive compounds that can be utilized through nanoemulsions for their applications in food and beverage industries. For example, the citrus (orange, grapefruit, mandarin, and lemon) essential oil-based nanoemulsions were investigated for their antioxidant and antimicrobial effects on rainbow trout fillets stored at refrigerated condition [172]. The nanoemulsions were able to restrict the growth of bacteria compared to the control group and could therefore be utilized for preserving other foods as well.

The mode of action of EOs against microbes depends on the biochemical profile and their ratio in crude EOs. Generally, the EOs disrupt the cellular structure of microbes by biochemical interactions with the cell membrane and cytoplasmic content leading to cell death $[22,173,174]$. Besides this, nanocarrier materials, such as alginate, cellulose, chitosan, cyclodextrin, dextran, and starch, can also alter membrane potential and the metabolic process, along with the generation of reactive oxygen species (ROS) similar to EOs for antimicrobial activity [175]. The greater surface area of nanoencapsulated EOs due to their small size provides an advantage for efficient interaction with microbial cell membranes at optimal doses [176]. Further, the delivery and release of the EOs at the targeted sites make them more effective against any microorganism [173]. Also, the EOs may act synergistically with carrier agents possessing antimicrobial properties, hence leading to the enhanced the antimicrobial activity of the nanoencapsulated EOs [177]. The applications of CEOs for food packaging and preservation are summarized in Table 5. 
Table 5. Application of CEOs for food packaging and preservation.

\begin{tabular}{|c|c|c|c|}
\hline CEO/Formulation & Packaging & Preservation & References \\
\hline Bergamot EO & $\begin{array}{c}\text { Chitosan and } \\
\text { hydroxypropylmethyl } \\
\text { cellulose (HPMC) edible } \\
\text { films }\end{array}$ & $\begin{array}{c}\text { Antibacterial activity against } \\
\text { Escherichia coli, Listeria } \\
\text { monocytogenes and Staphylococcus } \\
\text { aureus }\end{array}$ & [178] \\
\hline Bergamot EO & Gelatin edible films & $\begin{array}{c}\text { Antibacterial activity against } \\
\text { Staphylococcus aureus and Listeria } \\
\text { monocytogenes }\end{array}$ & [179] \\
\hline $\begin{array}{l}\text { Bergamot and bitter } \\
\text { orange EOs }\end{array}$ & $\begin{array}{l}\text { Chitosan and locust bean } \\
\text { gum edible films }\end{array}$ & $\begin{array}{c}\text { Effective against Aspergillus flavus } \\
\text { in dates }\end{array}$ & [180] \\
\hline $\begin{array}{l}\text { Bergamot, lemon and } \\
\text { mandarin EOs }\end{array}$ & $\begin{array}{l}\text { Modified chitosan } \\
\text { nanoemulsion coating }\end{array}$ & $\begin{array}{l}\text { Antimicrobial activity against } \\
\text { Escherichia coli O157:H7 and } \\
\text { Samonella typhimurium }\end{array}$ & [181] \\
\hline Bergamot EO & Chitosan coatings & $\begin{array}{l}\text { Protect oranges from Penicillium } \\
\text { italicum }\end{array}$ & [182] \\
\hline Lemon EO & $\begin{array}{l}\text { Novel edible coating } \\
\text { with modified chitosan } \\
\text { and nanoemulsified } \\
\text { lemon EO }\end{array}$ & $\begin{array}{l}\text { Increases antimicrobial activity } \\
\text { and prolongs the shelf life of } \\
\text { vegetable products }\end{array}$ & [183] \\
\hline Lemon EO & $\begin{array}{l}\text { Incorporated on to the } \\
\text { modified chitosan edible } \\
\text { coating }\end{array}$ & $\begin{array}{l}\text { Protects the storage-keeping } \\
\text { quality strawberries }\end{array}$ & [156] \\
\hline Lime EO & $\begin{array}{l}\text { Chitosan-based edible } \\
\text { coating }\end{array}$ & $\begin{array}{c}\text { Inhibition of Rhizopus stolonifera in } \\
\text { fresh tomato }\end{array}$ & [184] \\
\hline Lime EO & $\begin{array}{l}\text { Gum-based edible } \\
\text { coating }\end{array}$ & $\begin{array}{l}\text { Reduction of Colletotrichum } \\
\text { gloeosporioides and Rhizopus } \\
\text { stolonifer in fresh papaya }\end{array}$ & [127] \\
\hline Lemon EO & $\begin{array}{l}\text { Low density } \\
\text { polyethylene (LDPE) } \\
\text { films }\end{array}$ & $\begin{array}{l}\text { Acts as flavoring films for } \\
\text { packaging biscuit, prevents } \\
\text { changes in water-vapor } \\
\text { permeability and mechanical } \\
\text { properties }\end{array}$ & [185] \\
\hline Lemon EO & Chitosan & $\begin{array}{l}\text { Delayed ripening with a lower } \\
\text { respiration rate was observed in } \\
\text { strawberries coated with lemon } \\
\text { EO-based chitosan coatings }\end{array}$ & [186] \\
\hline Lemon EO & Chitosan & $\begin{array}{l}\text { Chitosan film combined with } \\
\text { lemon, thyme and cinnamon } \\
\text { essential oils provide a new } \\
\text { formulation for antimicrobial films }\end{array}$ & [187] \\
\hline $\begin{array}{l}\text { Citrus reticulata var. } \\
\text { tangerine } \mathrm{EO}\end{array}$ & $\begin{array}{l}\text { Nanoemulsions based on } \\
\text { chitosan nanoparticles }\end{array}$ & $\begin{array}{l}\text { Effective in preventing microbial } \\
\text { growth and lipid oxidation in } \\
\text { silvery pomfret and shows the } \\
\text { potential to preserve seafoods }\end{array}$ & [188] \\
\hline
\end{tabular}

\section{Future Concerns and Perspectives}

The application of CEOs for food packaging and preservation eliminates the need for synthetic preservatives. However, there are certain concerns regarding the use of CEOs. For example, CEOs can be used in meat and fish for preservation, but the active volatile compounds present in CEOs may interact with the proteins and produce undesirable compounds [166]. Further, the knowledge on how EOs interact with other components within food matrices and with other antimicrobial compounds is vital for food safety [189]. If a large amount of CEO is used to ensure the preservation, then they 
might alter the taste and aroma of food and ultimately the quality and consumer acceptance, since CEO provides a better taste and aroma at a low concentration. Furthermore, CEOs are nontoxic, hypoallergenic, and safe for consumption, but have caused skin irritation and allergies in some cases. However, this issue could be addressed by the microencapsulation of CEOs with suitable biodegradable coating materials that would provide an efficient controlled release of the biologically active compounds to the target site. This will also address the concerns associated with CEOs' instability and their interactions with food matrices (e.g., proteins), and further ensures that the biological activities of CEOs are unaltered through controlled release. In addition to this, the amount and composition of CEOs for their use in different food matrices are very crucial for food packaging and preservation aspects. Therefore, future research should focus on the efficient, affordable, and "green" extraction methods of CEOs, along with the optimum dose and safe limits, their interactions with various food matrices and packaging materials, possible allergic reactions, and their impacts on food quality and safety. Besides this, the use of biotechnology approaches involving genetic engineering should be utilized to develop disease-resistant Citrus plants in the first place [190].

\section{Conclusions}

CEOs are economic, ecofriendly, and natural alternatives to synthetic preservatives for food safety, packaging, and preservation. CEO-based edible films and coatings, microencapsulated biodegradable polymers, and nanoemulsion coatings can be applied for food packaging and preservation with enhanced antimicrobial properties. CEOs have the potential to reduce environmental pollution, substitute synthetic antimicrobials, and utilize byproducts of Citrus species in food processing industries. In addition, the antifungal properties of CEOs can be useful for the post-harvest disease control of fruits and vegetables in the agricultural industry. However, there are certain concerns regarding the optimum dose and safe limits, interactions with various food matrices and packaging materials, possible allergic reactions, and various advanced methods of encapsulating CEOs for efficient controlled release. These aspects require extensive and in-depth future research to ensure food safety and security.

Author Contributions: P.K. conceived and designed the manuscript; H.B., M.K., D.K.M., and P.K. wrote the manuscript; P.T. helped in the editing of the manuscript; P.K. critically reviewed the manuscript and did the required editing. All authors have read and agreed to the published version of the manuscript.

Funding: This research received no external funding.

Acknowledgments: All authors are highly grateful to the authority of the respective department and Institution for their support in conducting this research. Author (P.K.) would like to thank the DST-SERB (file no ECR/2017/001143) and DBT-Twinning (No. BT/PR24741/NER/95/659/2017) for their financial support.

Conflicts of Interest: There is no conflict of interest among the authors.

\section{References}

1. Anwar, F.; Naseer, R.; Bhanger, M.I.; Ashraf, S.; Talpur, F.N.; Aladedunye, F.A. Physico-chemical characteristics of citrus seeds and seed oils from Pakistan. J. Am. Oil Chem. Soc. 2008, 85, 321-330. [CrossRef]

2. Dosoky, N.S.; Setzer, W.N. Biological activities and safety of Citrus spp. essential oils. Int. J. Mol. Sci. 2018, 19, 1966. [CrossRef] [PubMed]

3. Wu, G.A.; Terol, J.; Ibanez, V.; López-García, A.; Pérez-Román, E.; Borredá, C.; Domingo, C.; Tadeo, F.R.; Carbonell-Caballero, J.; Alonso, R. Genomics of the origin and evolution of Citrus. Nature 2018, 554, 311-316. [CrossRef]

4. Mahato, N.; Sinha, M.; Sharma, K.; Koteswararao, R.; Cho, M.H. Modern Extraction and Purification Techniques for Obtaining High Purity Food-Grade Bioactive Compounds and Value-Added Co-Products from Citrus Wastes. Foods 2019, 8, 523. [CrossRef] [PubMed]

5. Schimmenti, E.; Borsellino, V.; Galati, A. Growth of citrus production among the Euro-Mediterranean countries: Political implications and empirical findings. Span. J. Agric. Res. 2013, 3, 561-577. [CrossRef] 
6. Duarte, A.; Carvalho, C.; Miguel, G. Bioactive compounds of citrus as health promoters. Nat. Bioact. Compd. Fruits Veg. Health Promot. 2016, 1, 29-97.

7. Duarte, A.; Fernandes, M.J.; Bernardes, J.P.; Miguel, M.G. Citrus as a component of the Mediterranean diet. JSOD 2016, 4, 289-304.

8. Ayaz, M.; Sadiq, A.; Junaid, M.; Ullah, F.; Subhan, F.; Ahmed, J. Neuroprotective and anti-aging potentials of essential oils from aromatic and medicinal plants. Front. Aging Neurosci. 2017, 9, 168. [CrossRef]

9. Chhikara, N.; Kour, R.; Jaglan, S.; Gupta, P.; Gat, Y.; Panghal, A. Citrus medica: Nutritional, phytochemical composition and health benefits-A review. Food Funct. 2018, 9, 1978-1992. [CrossRef]

10. Othman, M.; Atiqah, S.N.; Hassan, M.A.; Nahar, L.; Basar, N.; Jamil, S.; Sarker, S.D. Essential oils from the Malaysian Citrus (Rutaceae) medicinal plants. Medicines 2016, 3, 13. [CrossRef]

11. Palazzolo, E.; Laudicina, V.A.; Germanà, M.A. Current and potential use of citrus essential oils. Curr. Org. Chem. 2013, 17, 3042-3049. [CrossRef]

12. Wolffenbüttel, A.N.; Zamboni, A.; Becker, G.; Dos santos, M.K.; Borille, B.T.; De Cássia Mariotti, K.; Fagundes, A.C.; De oliveira salomón, J.L.; Coelho, V.R.; Ruiz, L.V. Citrus essential oils inhalation by mice: Behavioral testing, GCMS plasma analysis, corticosterone, and melatonin levels evaluation. Phytother. Res. 2018, 32, 160-169. [CrossRef] [PubMed]

13. Lawless, J. The Complete Illustrated Guide to Aromatherapy: A Practical Approach to the Use of Essential Oils for Health and Well-Being; HarperCollins: London, UK, 2002.

14. Conforti, F.; Statti, G.A.; Tundis, R.; Loizzo, M.R.; Menichini, F. In vitro activities of Citrus medica L. cv. Diamante (Diamante citron) relevant to treatment of diabetes and Alzheimer's disease. Phytother. Res. 2007, 21, 427-433. [CrossRef] [PubMed]

15. Cheng, S.-S.; Chung, M.-J.; Lin, C.-Y.; Wang, Y.-N.; Chang, S.-T. Phytochemicals from Cunninghamia konishii Hayata act as antifungal agents. J. Agric. Food Chem. 2011, 60, 124-128. [CrossRef]

16. Sheikh, M.; Safiuddin, A.; Khan, Z.; Rizvi, R.; Mahmood, I. Antibacterial and antifungal potential of some medicinal plants against certain phytopathogenic micro-organisms. Arch. Phytopathol. Plant Prot. 2013, 46, 1070-1080. [CrossRef]

17. Velázquez-Nuñez, M.J.; Avila-Sosa, R.; Palou, E.; López-Malo, A. Antifungal activity of orange (Citrus sinensis var. Valencia) peel essential oil applied by direct addition or vapor contact. Food Control. 2013, 31, 1-4. [CrossRef]

18. Souza, E.L.D.; Lima, E.D.O.; Freire, K.R.D.L.; Sousa, C.P.D. Inhibitory action of some essential oils and phytochemicals on the growth of various moulds isolated from foods. Braz. Arch. Biol. Technol. 2005, 48, 245-250. [CrossRef]

19. Chanthaphon, S.; Chanthachum, S.; Hongpattarakere, T. Antimicrobial activities of essential oils and crude extracts from tropical Citrus spp. against food-related microorganisms. Songklanakarin J. Sci. Technol. 2008, 30, 125-131.

20. Rammanee, K.; Hongpattarakere, T. Effects of tropical citrus essential oils on growth, aflatoxin production, and ultrastructure alterations of Aspergillus flavus and Aspergillus parasiticus. Food Bioprocess Technol. 2011, 4, 1050-1059. [CrossRef]

21. Fisher, K.; Phillips, C. Potential antimicrobial uses of essential oils in food: Is citrus the answer? Trends Food Sci. Technol. 2008, 19, 156-164. [CrossRef]

22. Calo, J.R.; Crandall, P.G.; O’Bryan, C.A.; Ricke, S.C. Essential oils as antimicrobials in food systems-A review. Food Control. 2015, 54, 111-119. [CrossRef]

23. Sharma, K.; Mahato, N.; Cho, M.H.; Lee, Y.R. Converting citrus wastes into value-added products: Economic and environmently friendly approaches. Nutrition 2017, 34, 29-46. [CrossRef] [PubMed]

24. Raimondo, M.; Caracciolo, F.; Cembalo, L.; Chinnici, G.; Pecorino, B.; D'Amico, M. Making Virtue Out of Necessity: Managing the Citrus Waste Supply Chain for Bioeconomy Applications. Sustainability 2018, 10, 4821. [CrossRef]

25. Shirsath, S.R.; Sonawane, S.H.; Gogate, P.R. Intensification of extraction of natural products using ultrasonic irradiations-A review of current status. Chem. Eng. Process. 2012, 53, 10-23. [CrossRef]

26. Panda, D.; Manickam, S. Cavitation technology-The future of greener extraction method: A review on the extraction of natural products and process intensification mechanism and perspectives. Appl. Sci. 2019, 9, 766. [CrossRef] 
27. Ozturk, B.; Gonzalez-Miquel, M. Alkanediol-based deep eutectic solvents for isolation of terpenoids from citrus essential oil: Experimental evaluation and COSMO-RS studies. Sep. Purif. Technol. 2019, 227, 115707. [CrossRef]

28. Pourbafrani, M.; McKechnie, J.; MacLean, H.L.; Saville, B.A. Life cycle greenhouse gas impacts of ethanol, biomethane and limonene production from citrus waste. Environ. Res. Lett. 2013, 8, 015007. [CrossRef]

29. Negro, V.; Mancini, G.; Ruggeri, B.; Fino, D. Citrus waste as feedstock for bio-based products recovery: Review on limonene case study and energy valorization. Bioresour. Technol. 2016, 214, 806-815. [CrossRef]

30. Banerjee, J.; Singh, R.; Vijayaraghavan, R.; MacFarlane, D.; Patti, A.F.; Arora, A. Bioactives from fruit processing wastes: Green approaches to valuable chemicals. Food Chem. 2017, 225, 10-22. [CrossRef]

31. Chemat, F.; Rombaut, N.; Sicaire, A.-G.; Meullemiestre, A.; Fabiano-Tixier, A.-S.; Abert-Vian, M. Ultrasound assisted extraction of food and natural products. Mechanisms, techniques, combinations, protocols and applications. A review. Ultrason. Sonochem. 2017, 34, 540-560. [CrossRef]

32. Ferrentino, G.; Asaduzzaman, M.; Scampicchio, M.M. Current technologies and new insights for the recovery of high valuable compounds from fruits by-products. Crit. Rev. Food Sci. Nutr. 2018, 58, 386-404. [CrossRef] [PubMed]

33. Flórez, N.; Conde, E.; Domínguez, H. Microwave assisted water extraction of plant compounds. J. Chem. Technol. Biotechnol. 2015, 90, 590-607. [CrossRef]

34. Rozzi, N.L.; Singh, R.K. Supercritical fluids and the food industry. Compr. Rev. Food Sci. Food Saf. 2002, 1, 33-44. [CrossRef]

35. Bustamante, J.; Van Stempvoort, S.; García-Gallarreta, M.; Houghton, J.A.; Briers, H.K.; Budarin, V.L.; Matharu, A.S.; Clark, J.H. Microwave assisted hydro-distillation of essential oils from wet citrus peel waste. J. Clean. Prod. 2016, 137, 598-605. [CrossRef]

36. Bousbia, N.; Vian, M.A.; Ferhat, M.A.; Meklati, B.Y.; Chemat, F. A new process for extraction of essential oil from Citrus peels: Microwave hydrodiffusion and gravity. J. Food Eng. 2009, 90, 409-413. [CrossRef]

37. Chemat, F.; Lucchesi, M.E.; Smadja, J.; Favretto, L.; Colnaghi, G.; Visinoni, F. Microwave accelerated steam distillation of essential oil from lavender: A rapid, clean and environmentally friendly approach. Anal. Chim. Acta 2006, 555, 157-160. [CrossRef]

38. Boukroufa, M.; Boutekedjiret, C.; Petigny, L.; Rakotomanomana, N.; Chemat, F. Bio-refinery of orange peels waste: A new concept based on integrated green and solvent free extraction processes using ultrasound and microwave techniques to obtain essential oil, polyphenols and pectin. Ultrason. Sonochem. 2015, 24, 72-79. [CrossRef]

39. Holkar, C.R.; Jadhav, A.J.; Pinjari, D.V.; Pandit, A.B. Cavitationally driven transformations: A technique of process intensification. Ind. Eng. Chem. Res. 2019, 58, 5797-5819. [CrossRef]

40. Meneguzzo, F.; Brunetti, C.; Fidalgo, A.; Ciriminna, R.; Delisi, R.; Albanese, L.; Zabini, F.; Gori, A.; Dos Santos Nascimento, L.B.; De Carlo, A. Real-Scale Integral Valorization of Waste Orange Peel via Hydrodynamic Cavitation. Processes 2019, 7, 581. [CrossRef]

41. Asaithambi, N.; Singha, P.; Dwivedi, M.; Singh, S.K. Hydrodynamic cavitation and its application in food and beverage industry: A review. J. Food Process Eng. 2019, 42, e13144. [CrossRef]

42. Albanese, L.; Meneguzzo, F. Hydrodynamic Cavitation Technologies: A Pathway to More Sustainable, Healthier Beverages, and Food Supply Chains. In Processing and Sustainability of Beverages; Woodhead Publishing, Elsevier: Sawston, UK, 2019; pp. 319-372.

43. Hilali, S.; Fabiano-Tixier, A.-S.; Ruiz, K.; Hejjaj, A.; Ait Nouh, F.; Idlimam, A.; Bily, A.; Mandi, L.; Chemat, F. Green extraction of essential oils, polyphenols, and pectins from orange peel employing solar energy: Toward a zero-waste biorefinery. ACS Sustain. Chem. Eng. 2019, 7, 11815-11822. [CrossRef]

44. Li, P.; Zeng, S.-L.; Duan, L.; Ma, X.-D.; Dou, L.-L.; Wang, L.-J.; Li, P.; Bi, Z.-M.; Liu, E.-H. Comparison of Aurantii Fructus Immaturus and Aurantii Fructus based on multiple chromatographic analysis and chemometrics methods. J. Chromatogr. A 2016, 1469, 96-107. [CrossRef] [PubMed]

45. Lota, M.-L.; De Rocca Serra, D.; Tomi, F.; Casanova, J. Chemical variability of peel and leaf essential oils of 15 species of mandarins. Biochem. Syst. Ecol. 2001, 29, 77-104. [CrossRef]

46. Quintero, A.; Gonzalez, C.N.; Sanchez, F.; Usubillaga, A.; Rojas, L. Constituents and biological activity of Citrus aurantium amara L. essential oil. In International Conference on Medicinal and Aromatic Plants (Part II); ISHS Acta Horticulturae 597: Leuven, Belgium, 2001; Volume 597, pp. 115-117. 
47. Jiang, M.H.; Yang, L.; Zhu, L.; Piao, J.H.; Jiang, J.G. Comparative GC/MS analysis of essential oils extracted by 3 methods from the bud of Citrus aurantium L. var. amara Engl. J. Food Sci. 2011, 76, C1219-C1225. [CrossRef] [PubMed]

48. Marti, G.; Boccard, J.; Mehl, F.; Debrus, B.; Marcourt, L.; Merle, P.; Delort, E.; Baroux, L.; Sommer, H.; Rudaz, S. Comprehensive profiling and marker identification in non-volatile citrus oil residues by mass spectrometry and nuclear magnetic resonance. Food Chem. 2014, 150, 235-245. [CrossRef] [PubMed]

49. Mehl, F.; Marti, G.; Boccard, J.; Debrus, B.; Merle, P.; Delort, E.; Baroux, L.; Raymo, V.; Velazco, M.I.; Sommer, H. Differentiation of lemon essential oil based on volatile and non-volatile fractions with various analytical techniques: A metabolomic approach. Food Chem. 2014, 143, 325-335. [CrossRef]

50. Rahimi, A.; Hashemi, P.; Talei, G.R.; Borzuei, M.; Ghiasvand, A.R. Comparative analyses of the volatile components of Citrus aurantium L. flowers using ultrasonic-assisted headspace SPME and hydrodistillation combined with GC-MS and evaluation of their antimicrobial activities. Anal. Bioanal. Chem. Res. 2014, 1, 83-91.

51. Parastar, H.; Jalali-Heravi, M.; Sereshti, H.; Mani-Varnosfaderani, A. Chromatographic fingerprint analysis of secondary metabolites in citrus fruits peels using gas chromatography-mass spectrometry combined with advanced chemometric methods. J. Chromatogr. A 2012, 1251, 176-187. [CrossRef]

52. Schulz, H.; Quilitzsch, R.; Krüger, H. Rapid evaluation and quantitative analysis of thyme, origano and chamomile essential oils by ATR-IR and NIR spectroscopy. J. Mol. Struct. 2003, 661, 299-306. [CrossRef]

53. Taghadomi-Saberi, S.; Mas Garcia, S.; Allah Masoumi, A.; Sadeghi, M.; Marco, S. Classification of bitter orange essential oils according to fruit ripening stage by untargeted chemical profiling and machine learning. Sensors 2018, 18, 1922. [CrossRef]

54. Djenane, D. Chemical profile, antibacterial and antioxidant activity of Algerian citrus essential oils and their application in Sardina pilchardus. Foods 2015, 4, 208-228. [CrossRef] [PubMed]

55. Hsouna, A.B.; Hamdi, N.; Halima, N.B.; Abdelkafi, S. Characterization of essential oil from Citrus aurantium L. flowers: Antimicrobial and antioxidant activities. J. Oleo Sci. 2013, 62, 763-772. [CrossRef]

56. Haj Ammar, A.; Bouajila, J.; Lebrihi, A.; Mathieu, F.; Romdhane, M.; Zagrouba, F. Chemical composition and in vitro antimicrobial and antioxidant activities of Citrus aurantium L. flowers essential oil (Neroli oil). Pak. J. Biol. Sci. 2012, 15, 1034-1040. [CrossRef] [PubMed]

57. Salma, M.; Abdellah, F.; El Houssine, A.; Kawtar, B.; Dalila, B. Comparison of the chemical composition and the bioactivity of the essential oils of three medicinal and aromatic plants from Jacky Garden of Morocco. Int. J. Pharm. Phytochem. Res. 2016, 8, 537-545.

58. Sarrou, E.; Chatzopoulou, P.; Dimassi-Theriou, K.; Therios, I. Volatile constituents and antioxidant activity of peel, flowers and leaf oils of Citrus aurantium L. growing in Greece. Molecules 2013, 18, 10639-10647. [CrossRef] [PubMed]

59. Bonaccorsi, I.; Sciarrone, D.; Schipilliti, L.; Trozzi, A.; Fakhry, H.A.; Dugo, G. Composition of Egyptian nerolì oil. Nat. Prod. Commun. 2011, 6, 1009-1014. [CrossRef]

60. Labadie, C.; Ginies, C.; Guinebretiere, M.-H.; Renard, C.M.G.C.; Cerutti, C.; Carlin, F. Hydrosols of orange blossom (Citrus aurantium), and rose flower (Rosa damascena and Rosa centifolia) support the growth of a heterogeneous spoilage microbiota. Food Res. Int. 2015, 76, 576-586. [CrossRef]

61. Allaf, T.; Tomao, V.; Ruiz, K.; Chemat, F. Instant controlled pressure drop technology and ultrasound assisted extraction for sequential extraction of essential oil and antioxidants. Ultrason. Sonochem. 2013, 20, 239-246. [CrossRef]

62. Ferhat, M.A.; Meklati, B.Y.; Chemat, F. Comparison of different isolation methods of essential oil from Citrus fruits: Cold pressing, hydrodistillation and microwave 'dry'distillation. Flavour Fragr. J. 2007, 22, 494-504. [CrossRef]

63. Shakir, I.K.; Salih, S.J. Extraction of essential oils from citrus by-products using microwave steam distillation. Iraqi J. Chem. Pet. Eng. 2015, 16, 11-22.

64. Kusuma, H.; Putra, A.F.P.; Mahfud, M. Comparison of two isolation methods for essential oils from orange peel (Citrus auranticum L.) as a growth promoter for fish: Microwave steam distillation and conventional steam distillation. J. Aquac. Res. Dev. 2016, 7, 409.

65. Merle, H.; Morón, M.; Blázquez, M.A.; Boira, H. Taxonomical contribution of essential oils in mandarins cultivars. Biochem. Syst. Ecol. 2004, 32, 491-497. [CrossRef] 
66. Ahmad, M.M.; Iqbal, Z.; Anjum, F.M.; Sultan, J.I. Genetic variability to essential oil composition in four citrus fruit species. Pak. J. Bot. 2006, 38, 319.

67. Burt, S. Essential oils: Their antibacterial properties and potential applications in foods-A review. Int. J. Food Microbiol. 2004, 94, 223-253. [CrossRef] [PubMed]

68. Droby, S.; Eick, A.; Macarisin, D.; Cohen, L.; Rafael, G.; Stange, R.; McColum, G.; Dudai, N.; Nasser, A.; Wisniewski, M. Role of citrus volatiles in host recognition, germination and growth of Penicillium digitatum and Penicillium italicum. Postharvest Biol. Technol. 2008, 49, 386-396. [CrossRef]

69. Bakkali, F.; Averbeck, S.; Averbeck, D.; Idaomar, M. Biological effects of essential oils-a review. Food Chem. Toxicol. 2008, 46, 446-475. [CrossRef]

70. Smith, D.C.; Forland, S.; Bachanos, E.; Matejka, M.; Barrett, V. Qualitative analysis of citrus fruit extracts by GC/MS: An undergraduate experiment. Chem. Educ. 2001, 6, 28-31. [CrossRef]

71. Moufida, S.D.; Marzouk, B. Biochemical characterization of blood orange, sweet orange, lemon, bergamot and bitter orange. Phytochemistry 2003, 62, 1283-1289. [CrossRef]

72. Bhuiyan, M.N.I.; Begum, J.; Sardar, P.K.; Rahman, M.S. Constituents of peel and leaf essential oils of Citrus medica L. J. Sci. Res. 2009, 1, 387-392. [CrossRef]

73. Al-Aamri, M.S.; Al-Abousi, N.M.; Al-Jabri, S.S.; Alam, T.; Khan, S.A. Chemical composition and In-Vitro antioxidant and antimicrobial activity of the essential oil of Citrus aurantifolia L. leaves grown in Eastern Oman. J. Taibah Univ. Med. Sci. 2018, 13, 108-112. [CrossRef]

74. Suwannayod, S.; Sukontason, K.L.; Somboon, P.; Junkum, A.; Leksomboon, R.; Chaiwong, T.; Jones, M.K.; Sripa, B.; Balthaisong, S.; Phuyao, C. Activity of kaffirlime (Citrus hystrix) essential oil against blow flies and housefly. Southeast Asian J. Trop. Med. Public Health 2018, 49, 32-45.

75. Hosni, K.; Zahed, N.; Chrif, R.; Abid, I.; Medfei, W.; Kallel, M.; Brahim, N.B.; Sebei, H. Composition of peel essential oils from four selected Tunisian Citrus species: Evidence for the genotypic influence. Food Chem. 2010, 123, 1098-1104. [CrossRef]

76. Lota, M.-L.; De Rocca Serra, D.; Tomi, F.; Jacquemond, C.; Casanova, J. Volatile components of peel and leaf oils of lemon and lime species. J. Agric. Food Chem. 2002, 50, 796-805. [CrossRef] [PubMed]

77. Jing, L.; Zhang, Y.; Fan, S.; Gu, M.; Guan, Y.; Lu, X.; Huang, C.; Zhou, Z. Preventive and ameliorating effects of citrus $d$-limonene on dyslipidemia and hyperglycemia in mice with high-fat diet-induced obesity. Eur. J. Pharmacol. 2013, 715, 46-55. [CrossRef] [PubMed]

78. Jabalpurwala, F.A.; Smoot, J.M.; Rouseff, R.L. A comparison of citrus blossom volatiles. Phytochemistry 2009, 70, 1428-1434. [CrossRef]

79. Sartorelli, P.; Marquioreto, A.D.; Amaral-Baroli, A.; Lima, M.E.L.; Moreno, P.R.H. Chemical composition and antimicrobial activity of the essential oils from two species of Eucalyptus. Phytother. Res. 2007, 21, 231-233. [CrossRef]

80. Bourgou, S.; Rahali, F.Z.; Ourghemmi, I.; Saïdani Tounsi, M. Changes of peel essential oil composition of four Tunisian citrus during fruit maturation. Sci. World J. 2012, 2012, 528593. [CrossRef]

81. Vallianou, I.; Peroulis, N.; Pantazis, P.; Hadzopoulou-Cladaras, M. Camphene, a plant-derived monoterpene, reduces plasma cholesterol and triglycerides in hyperlipidemic rats independently of HMG-CoA reductase activity. PLoS ONE 2011, 6, e20516. [CrossRef]

82. Hammer, K.A.; Carson, C.F.; Riley, T.V. Antifungal activity of the components of Melaleuca alternifolia (tea tree) oil. J. Appl. Microbiol. 2003, 95, 853-860. [CrossRef]

83. Park, I.-K.; Lee, S.-G.; Choi, D.-H.; Park, J.-D.; Ahn, Y.-J. Insecticidal activities of constituents identified in the essential oil from leaves of Chamaecyparis obtusa against Callosobruchus chinensis (L.) and Sitophilus oryzae (L.). J. Stored Prod. Res. 2003, 39, 375-384. [CrossRef]

84. Tao, N.; Jia, L.; Zhou, H. Anti-fungal activity of Citrus reticulata Blanco essential oil against Penicillium italicum and Penicillium digitatum. Food Chem. 2014, 153, 265-271. [CrossRef] [PubMed]

85. Zhu, T.; Zhao, Y.; Zhang, J.; Li, L.; Zou, L.; Yao, Y.; Xu, Y. ss-Elemene inhibits proliferation of human glioblastoma cells and causes cell-cycle G0/G1 arrest via mutually compensatory activation of MKK3 and MKK6. Int. J. Oncol. 2011, 38, 419-426. [PubMed]

86. Nishida, R.; Shelly, T.E.; Whittier, T.S.; Kaneshiro, K.Y. $\alpha$-Copaene, a potential rendezvous cue for the Mediterranean fruit fly, Ceratitis capitata? J. Chem. Ecol. 2000, 26, 87-100. [CrossRef]

87. Legault, J.; Pichette, A. Potentiating effect of $\beta$-caryophyllene on anticancer activity of $\alpha$-humulene, isocaryophyllene and paclitaxel. J. Pharm. Pharmacol. 2007, 59, 1643-1647. [CrossRef] [PubMed] 
88. Wuryatmo, E.; Klieber, A.; Scott, E.S. Inhibition of citrus postharvest pathogens by vapor of citral and related compounds in culture. J. Agric. Food Chem. 2003, 51, 2637-2640. [CrossRef] [PubMed]

89. Chen, W.; Viljoen, A.M. Geraniol-A review of a commercially important fragrance material. S. Afr. J. Bot. 2010, 76, 643-651. [CrossRef]

90. Kotan, R.; Kordali, S.; Cakir, A. Screening of antibacterial activities of twenty-one oxygenated monoterpenes. Z. Naturforsch. C 2007, 62, 507-513. [CrossRef]

91. Deepa, B.; Anuradha, C.V. Linalool, a plant derived monoterpene alcohol, rescues kidney from diabetes-induced nephropathic changes via blood glucose reduction. Diabetol. Croat. 2011, 40, 121-137.

92. Betancur-Galvis, L.; Zapata, B.; Baena, A.; Bueno, J.; Ruíz-Nova, C.A.; Stashenko, E.; Mesa-Arango, A.C. Antifungal, cytotoxic and chemical analyses of essential oils of Lippia origanoides HBK grown in Colombia. Rev. Univ. Ind. Santander Salud 2011, 43, 141-148.

93. Gormez, A.; Bozari, S.; Yanmis, D.; Gulluce, M.; Agar, G.; Sahin, F. The use of essential oils of Origanum rotundifolium as antimicrobial agent against plant pathogenic bacteria. J. Essent. Oil Bear. Plants 2016, 19, 656-663. [CrossRef]

94. Pandey, A.K.; Kumar, P.; Singh, P.; Tripathi, N.N.; Bajpai, V.K. Essential oils: Sources of antimicrobials and food preservatives. Front. Microbiol. 2017, 7, 2161. [CrossRef] [PubMed]

95. Pandey, A.K.; Singh, P.; Tripathi, N.N. Impact of essential oils on eggs hatchability and feeding activity of pulse beetles. J. Entomol. Res. 2011, 35, 221-225.

96. Sonker, N.; Pandey, A.K.; Singh, P. Efficiency of Artemisia nilagirica (Clarke) Pamp. essential oil as a mycotoxicant against postharvest mycobiota of table grapes. J. Sci. Food Agric. 2015, 95, 1932-1939. [CrossRef] [PubMed]

97. Tripathi, N.N.; Kumar, N. Putranjiva roxburghii oil-A potential herbal preservative for peanuts during storage. J. Stored Prod. Res. 2007, 43, 435-442. [CrossRef]

98. Kamle, M.; Mahato, D.K.; Lee, K.E.; Bajpai, V.K.; Gajurel, P.R.; Gu, K.S.; Kumar, P. Ethnopharmacological properties and medicinal uses of Litsea cubeba. Plants 2019, 8, 150. [CrossRef]

99. Kristensen, M.; Knorr, M.; Spencer, A.G.; Jespersen, J.B. Selection and reversion of azamethiphos-resistance in a field population of the housefly Musca domestica (Diptera: Muscidae), and the underlying biochemical mechanisms. J. Econ. Entomol. 2000, 93, 1788-1795. [CrossRef]

100. World Health Organization. Vector Control Series: The Housefly: Training and Information Guide; World Health Organization: Geneva, Switzerland, 1986.

101. Kristensen, M.; Jespersen, J.B. Larvicide resistance in Musca domestica (Diptera: Muscidae) populations in Denmark and establishment of resistant laboratory strains. J. Econ. Entomol. 2003, 96, 1300-1306. [CrossRef]

102. Kumar, P.; Mishra, S.; Malik, A.; Satya, S. Insecticidal evaluation of essential oils of Citrus sinensis L. (Myrtales: Myrtaceae) against housefly, Musca domestica L. (Diptera: Muscidae). Parasitol. Res. 2012, 110, 1929-1936. [CrossRef]

103. Abad, M.K.R.; Besheli, B.A. Insecticidal potential of essential oil from the leaves of Citrus aurantium L. against Oryzaephilus surinamensis (F.), Lasioderma serricorne (L.) and Sitophilus oryzae (L.). J. Entomol. Zool. Stud. 2016, 4, 865-869.

104. Sarma, R.; Khanikor, B.; Mahanta, S. Essential oil from Citrus grandis (Sapindales: Rutaceae) as insecticide against Aedes aegypti (L) (Diptera: Culicidae). Int. J. Mosq. Res. 2017, 4, 88-92.

105. Chungsamarnyart, N.; Jansawan, W. Acaricidal activity of peel oil of Citrus spp. on Boophilus microplus. Kasetsart J. (Nat. Sci.) 1996, 30, 112-117.

106. Klauck, V.; Pazinato, R.; Volpato, A.; Dos Santos, D.D.S.; Santos, R.C.V.; Baldissera, M.D.; Da Silva, A.S. Insecticidal effect of several essential oils against Musca domestica. Comp. Clin. Pathol. 2018, 27, 167-172. [CrossRef]

107. Campolo, O.; Cherif, A.; Ricupero, M.; Siscaro, G.; Grissa-Lebdi, K.; Russo, A.; Cucci, L.M.; Di Pietro, P.; Satriano, C.; Desneux, N. Citrus peel essential oil nanoformulations to control the tomato borer, Tuta absoluta: Chemical properties and biological activity. Sci. Rep. 2017, 7, 13036. [CrossRef] [PubMed]

108. Oboh, G.; Ademosun, A.O.; Olumuyiwa, T.A.; Olasehinde, T.A.; Ademiluyi, A.O.; Adeyemo, A.C. Insecticidal activity of essential oil from orange peels (Citrus sinensis) against Tribolium confusum, Callosobruchus maculatus and Sitophilus oryzae and its inhibitory effects on acetylcholinesterase and $\mathrm{Na}+/ \mathrm{K}+$-ATPase activities. Phytoparasitica 2017, 45, 501-508. [CrossRef] 
109. Sanei-Dehkordi, A.; Sedaghat, M.M.; Vatandoost, H.; Abai, M.R. Chemical compositions of the peel essential oil of Citrus aurantium and its natural larvicidal activity against the malaria vector Anopheles stephensi (Diptera: Culicidae) in comparison with Citrus paradisi. J. Arthropod Borne Dis. 2016, 10, 577.

110. Oikeh, E.I.; Omoregie, E.S.; Oviasogie, F.E.; Oriakhi, K. Phytochemical, antimicrobial, and antioxidant activities of different citrus juice concentrates. Food Sci. Nutr. 2016, 4, 103-109. [CrossRef]

111. Sahlan, M.; Damayanti, V.; Tristantini, D.; Hermansyah, H.; Wijanarko, A.; Olivia, Y. Antimicrobial Activities of Pummelo (Citrus maxima) Seed and Pulp Ethanolic Extract. AIP Conf. Proc. 2018, 1993. [CrossRef]

112. Mehmood, T.; Afzal, A.; Anwar, F.; Iqbal, M.; Afzal, M.; Qadir, R. Variations in the Composition, Antibacterial and Haemolytic Activities of Peel Essential Oils from Unripe and Ripened Citrus limon (L.) Osbeck Fruit. J. Essent. Oil Bear. Plants 2019, 22, 159-168. [CrossRef]

113. Chen, Y.; Li, T.; Bai, J.; Nong, L.; Ning, Z.; Hu, Z.; Xu, A.; Xu, C.-P. Chemical Composition and Antibacterial Activity of the Essential Oil of Citrus maxima (Burm.) Merr. cv. Shatian Yu. J. Biol. Act. Prod. Nat. 2018, 8, 228-233.

114. Bnina, E.B.; Hajlaoui, H.; Chaieb, I.; Said, M.B.; Jannet, H.B. Chemical composition, antimicrobial and insecticidal activities of the tunisian Citrus aurantium essential oils. Czech J. Food Sci. 2019, 37, 81-92. [CrossRef]

115. Qadir, R.; Farooq Anwar, T.M.; Shahid, M.; Zahoor, S. Variations in chemical composition, antimicrobial and haemolytic activities of peel essential oils from three local Citrus cultivars. Pure Appl. Biol. 2018, 7, 282-291. [CrossRef]

116. Li, Y.; Wu, C.; Wu, T.; Yuan, C.; Hu, Y. Antioxidant and antibacterial properties of coating with chitosan-citrus essential oil and effect on the quality of Pacific mackerel during chilled storage. Food Sci. Nutr. 2019, 7, 1131-1143. [CrossRef] [PubMed]

117. Fisher, K.; Rowe, C.; Phillips, C.A. The survival of three strains of Arcobacter butzleri in the presence of lemon, orange and bergamot essential oils and their components in vitro and on food. Lett. Appl. Microbiol. 2007, 44, 495-499. [CrossRef]

118. Sonboli, A.; Eftekhar, F.; Yousefzadi, M.; Kanani, M.R. Antibacterial activity and chemical composition of the essential oil of Grammosciadium platycarpum Boiss. from Iran. Z. Naturforsch. C 2005, 60, 30-34. [CrossRef] [PubMed]

119. Furneri, P.M.; Mondello, L.; Mandalari, G.; Paolino, D.; Dugo, P.; Garozzo, A.; Bisignano, G. In Vitro antimycoplasmal activity of Citrus bergamia essential oil and its major components. Eur. J. Med. Chem. 2012, 52, 66-69. [CrossRef]

120. Di Pasqua, R.; Hoskins, N.; Betts, G.; Mauriello, G. Changes in membrane fatty acids composition of microbial cells induced by addiction of thymol, carvacrol, limonene, cinnamaldehyde, and eugenol in the growing media. J. Agric. Food Chem. 2006, 54, 2745-2749. [CrossRef] [PubMed]

121. Fisher, K.; Phillips, C.A. The effect of lemon, orange and bergamot essential oils and their components on the survival of Campylobacter jejuni, Escherichia coli O157, Listeria monocytogenes, Bacillus cereus and Staphylococcus aureus in vitro and in food systems. J. Appl. Microbiol. 2006, 101, 1232-1240. [CrossRef]

122. Değirmenci, H.; Erkurt, H. Relationship between volatile components, antimicrobial and antioxidant properties of the essential oil, hydrosol and extracts of Citrus aurantium L. flowers. J. Infect. Public Health 2020, 13, 58-67. [CrossRef]

123. Prabuseenivasan, S.; Jayakumar, M.; Ignacimuthu, S. In vitro antibacterial activity of some plant essential oils. BMC Complement. Altern. Med. 2006, 6, 39. [CrossRef]

124. Sultana, H.S.; Ali, M.; Panda, B.P. Influence of volatile constituents of fruit peels of Citrus reticulata Blanco on clinically isolated pathogenic microorganisms under In-Vitro. Asian Pac. J. Trop. Biomed. 2012, 2, S1299-S1302. [CrossRef]

125. Fabio, A.; Cermelli, C.; Fabio, G.; Nicoletti, P.; Quaglio, P. Screening of the antibacterial effects of a variety of essential oils on microorganisms responsible for respiratory infections. Phytother. Res. 2007, 21, 374-377. [CrossRef]

126. Da Cruz Cabral, L.; Pinto, V.F.; Patriarca, A. Application of plant derived compounds to control fungal spoilage and mycotoxin production in foods. Int. J. Food Microbiol. 2013, 166, 1-14. [CrossRef] [PubMed]

127. Bosquez-Molina, E.; Ronquillo-de Jesús, E.; Bautista-Baños, S.; Verde-Calvo, J.R.; Morales-López, J. Inhibitory effect of essential oils against Colletotrichum gloeosporioides and Rhizopus stolonifer in stored papaya fruit and their possible application in coatings. Postharvest Biol. Technol. 2010, 57, 132-137. [CrossRef] 
128. Sharma, N.; Tripathi, A. Effects of Citrus sinensis (L.) Osbeck epicarp essential oil on growth and morphogenesis of Aspergillus niger (L.) Van Tieghem. Microbiol. Res. 2008, 163, 337-344. [CrossRef] [PubMed]

129. Ammad, F.; Moumen, O.; Gasem, A.; Othmane, S.; Hisashi, K.-N.; Zebib, B.; Merah, O. The potency of lemon (Citrus limon L.) essential oil to control some fungal diseases of grapevine wood. C. R. Biol. 2018, 341, 97-101. [CrossRef] [PubMed]

130. Chutia, M.; Bhuyan, P.D.; Pathak, M.G.; Sarma, T.C.; Boruah, P. Antifungal activity and chemical composition of Citrus reticulata Blanco essential oil against phytopathogens from North East India. LWT-Food Sci. Technol. 2009, 42, 777-780. [CrossRef]

131. Lamine, M.; Rahali, F.Z.; Hammami, M.; Mliki, A. Correlative metabolite profiling approach to understand antioxidant and antimicrobial activities from citrus essential oils. Int. J. Food Sci. Technol. 2019, 54, 2615-2623. [CrossRef]

132. Singh, P.; Shukla, R.; Prakash, B.; Kumar, A.; Singh, S.; Mishra, P.K.; Dubey, N.K. Chemical profile, antifungal, antiaflatoxigenic and antioxidant activity of Citrus maxima Burm. and Citrus sinensis (L.) Osbeck essential oils and their cyclic monoterpene, DL-limonene. Food Chem. Toxicol. 2010, 48, 1734-1740. [CrossRef]

133. Tao, N.G.; Liu, Y.J.; Zhang, M.L. Chemical composition and antimicrobial activities of essential oil from the peel of bingtang sweet orange (Citrus sinensis Osbeck). Int. J. Food Sci. Technol. 2009, 44, 1281-1285. [CrossRef]

134. Caccioni, D.R.L.; Guizzardi, M.; Biondi, D.M.; Renda, A.; Ruberto, G. Relationship between volatile components of citrus fruit essential oils and antimicrobial action on Penicillium digitatum and Penicillium italicum. Int. J. Food Microbiol. 1998, 43, 73-79. [CrossRef]

135. Van Hung, P.; Chi, P.T.L.; Phi, N.T.L. Comparison of antifungal activities of Vietnamese citrus essential oils. Nat. Prod. Res. 2013, 27, 506-508. [CrossRef] [PubMed]

136. Sharma, N.; Tripathi, A. Fungitoxicity of the essential oil of Citrus sinensis on post-harvest pathogens. World J. Microbiol. Biotechnol. 2006, 22, 587-593. [CrossRef]

137. Carocho, M.; Morales, P.; Ferreira, I.C.F.R. Natural food additives: Quo vadis? Trends Food Sci. Technol. 2015, 45, 284-295. [CrossRef]

138. Robertson, G.L. Introduction to food packaging. In Food Packing: Principles and Practice, 3rd ed.; CRC Press, Taylor \& Francis Group: Boca Raton, FL, USA, 2012; pp. 1-8.

139. Véronique, C.O.M.A. Bioactive packaging technologies for extended shelf life of meat-based products. Meat Sci. 2008, 78, 90-103.

140. Dainelli, D.; Gontard, N.; Spyropoulos, D.; Zondervan-van den Beuken, E.; Tobback, P. Active and intelligent food packaging: Legal aspects and safety concerns. Trends Food Sci. Technol. 2008, 19, S103-S112. [CrossRef]

141. Ozdemir, M.; Floros, J.D. Active food packaging technologies. Crit. Rev. Food Sci. Nutr. 2004, 44, $185-193$. [CrossRef] [PubMed]

142. Suppakul, P.; Miltz, J.; Sonneveld, K.; Bigger, S.W. Active packaging technologies with an emphasis on antimicrobial packaging and its applications. J. Food Sci. 2003, 68, 408-420. [CrossRef]

143. Vermeiren, L.; Devlieghere, F.; De Kruijf, N.; Debevere, J. Development in the active packaging of foods. J. Food Technol. Afr. 2000, 5, 6-13. [CrossRef]

144. Petersen, K.; Nielsen, P.V.; Bertelsen, G.; Lawther, M.; Olsen, M.B.; Nilsson, N.H.; Mortensen, G. Potential of biobased materials for food packaging. Trends Food Sci. Technol. 1999, 10, 52-68. [CrossRef]

145. Bao, S.; Xu, S.; Wang, Z. Antioxidant activity and properties of gelatin films incorporated with tea polyphenol-loaded chitosan nanoparticles. J. Sci. Food Agric. 2009, 89, 2692-2700. [CrossRef]

146. Limpan, N.; Prodpran, T.; Benjakul, S.; Prasarpran, S. Properties of biodegradable blend films based on fish myofibrillar protein and polyvinyl alcohol as influenced by blend composition and $\mathrm{pH}$ level. J. Food Eng. 2010, 100, 85-92. [CrossRef]

147. Ojagh, S.M.; Rezaei, M.; Razavi, S.H.; Hosseini, S.M.H. Effect of chitosan coatings enriched with cinnamon oil on the quality of refrigerated rainbow trout. Food Chem. 2010, 120, 193-198. [CrossRef]

148. Aşik, E.; Candoğan, K. Effects of chitosan coatings incorporated with garlic oil on quality characteristics of shrimp. J. Food Qual. 2014, 37, 237-246. [CrossRef]

149. Aider, M. Chitosan application for active bio-based films production and potential in the food industry. LWT-Food Sci. Technol. 2010, 43, 837-842. [CrossRef]

150. Sánchez-González, L.; Vargas, M.; González-Martínez, C.; Chiralt, A.; Chafer, M. Use of essential oils in bioactive edible coatings: A review. Food Eng. Rev. 2011, 3, 1-16. [CrossRef] 
151. Persico, P.; Ambrogi, V.; Carfagna, C.; Cerruti, P.; Ferrocino, I.; Mauriello, G. Nanocomposite polymer films containing carvacrol for antimicrobial active packaging. Polym. Eng. Sci. 2009, 49, 1447-1455. [CrossRef]

152. Viuda-Martos, M.; Ruiz-Navajas, Y.; Fernández-López, J.; Pérez-Álvarez, J. Antifungal activity of lemon (Citrus lemon L.), mandarin (Citrus reticulata L.), grapefruit (Citrus paradisi L.) and orange (Citrus sinensis L.) essential oils. Food Control. 2008, 19, 1130-1138. [CrossRef]

153. Xing, Y.; Li, X.; Xu, Q.; Yun, J.; Lu, Y.; Tang, Y. Effects of chitosan coating enriched with cinnamon oil on qualitative properties of sweet pepper (Capsicum annuum L.). Food Chem. 2011, 124, 1443-1450. [CrossRef]

154. Sánchez-González, L.; Pastor, C.; Vargas, M.; Chiralt, A.; González-Martínez, C.; Cháfer, M. Effect of hydroxypropylmethylcellulose and chitosan coatings with and without bergamot essential oil on quality and safety of cold-stored grapes. Postharvest Biol. Technol. 2011, 60, 57-63. [CrossRef]

155. Vu, K.D.; Hollingsworth, R.G.; Leroux, E.; Salmieri, S.; Lacroix, M. Development of edible bioactive coating based on modified chitosan for increasing the shelf life of strawberries. Food Res. Int. 2011, 44, 198-203. [CrossRef]

156. Perdones, A.; Sánchez-González, L.; Chiralt, A.; Vargas, M. Effect of chitosan-lemon essential oil coatings on storage-keeping quality of strawberry. Postharvest Biol. Technol. 2012, 70, 32-41. [CrossRef]

157. Alparslan, Y.; Yapıcı, H.H.; Metin, C.; Baygar, T.; Günlü, A.; Baygar, T. Quality assessment of shrimps preserved with orange leaf essential oil incorporated gelatin. LWT-Food Sci. Technol. 2016, 72, 457-466. [CrossRef]

158. Alparslan, Y.; Baygar, T. Effect of chitosan film coating combined with orange peel essential oil on the shelf life of deepwater pink shrimp. Food Bioprocess Technol. 2017, 10, 842-853. [CrossRef]

159. Randazzo, W.; Jiménez-Belenguer, A.; Settanni, L.; Perdones, A.; Moschetti, M.; Palazzolo, E.; Guarrasi, V.; Vargas, M.; Germanà, M.A.; Moschetti, G. Antilisterial effect of citrus essential oils and their performance in edible film formulations. Food Control. 2016, 59, 750-758. [CrossRef]

160. Chiabrando, V.; Giacalone, G. Effects of citrus essential oils incorporated in alginate coating on quality of fresh-cut Jintao kiwifruit. J. Food Nutr. Res. 2019, 58, 177-186.

161. Gomes, M.D.S.; Cardoso, M.D.G.; Guimarães, A.C.G.; Guerreiro, A.C.; Gago, C.M.L.; Vilas Boas, E.V.D.B.; Dias, C.M.B.; Manhita, A.C.C.; Faleiro, M.L.; Miguel, M.G.C. Effect of edible coatings with essential oils on the quality of red raspberries over shelf-life. J. Sci. Food Agric. 2017, 97, 929-938. [CrossRef] [PubMed]

162. Do Evangelho, J.A.; Da Silva Dannenberg, G.; Biduski, B.; El Halal, S.L.M.; Kringel, D.H.; Gularte, M.A.; Fiorentini, A.M.; Da Rosa Zavareze, E. Antibacterial activity, optical, mechanical, and barrier properties of corn starch films containing orange essential oil. Carbohydr. Polym. 2019, 222, 114981. [CrossRef]

163. Dehghan, H.; Roomiani, L. Antimicrobial Activity of Nanoclay Films Enriched with Citrus aurantium Essential Oil against Indicator FoodBorne Pathogens in Fishery Products. Iranian J. Nutr. Sci. Food Technol. 2020, 14, 103-111.

164. Jafari, S.M.; Assadpoor, E.; He, Y.; Bhandari, B. Encapsulation efficiency of food flavours and oils during spray drying. Dry. Technol. 2008, 26, 816-835. [CrossRef]

165. Gouin, S. Microencapsulation: Industrial appraisal of existing technologies and trends. Trends Food Sci. Technol. 2004, 15, 330-347. [CrossRef]

166. Mahato, N.; Sharma, K.; Koteswararao, R.; Sinha, M.; Baral, E.; Cho, M.H. Citrus essential oils: Extraction, authentication and application in food preservation. Crit. Rev. Food Sci. Nutr. 2019, 59, 611-625. [CrossRef]

167. Fang, Z.; Bhandari, B. Encapsulation of polyphenols-A review. Trends Food Sci. Technol. 2010, 21, 510-523. [CrossRef]

168. Fernandes, R.V.D.B.; Borges, S.V.; Botrel, D.A.; Oliveira, C.R.D. Physical and chemical properties of encapsulated rosemary essential oil by spray drying using whey protein-inulin blends as carriers. Int. J. Food Sci. Technol. 2014, 49, 1522-1529. [CrossRef]

169. Raksa, A.; Sawaddee, P.; Raksa, P.; Aldred, A.K. Microencapsulation, chemical characterization, and antibacterial activity of Citrus hystrix DC (Kaffir Lime) peel essential oil. Monatsh. Chem. Chem. Mon. 2017, 148, 1229-1234. [CrossRef] 
170. De Araújo, J.S.F.; De Souza, E.L.; Oliveira, J.R.; Gomes, A.C.A.; Kotzebue, L.R.V.; Da Silva Agostini, D.L.; De Oliveira, D.L.V.; Mazzetto, S.E.; Da Silva, A.L.; Cavalcanti, M.T. Microencapsulation of sweet orange essential oil (Citrus aurantium var. dulcis) by liophylization using maltodextrin and maltodextrin/gelatin mixtures: Preparation, characterization, antimicrobial and antioxidant activities. Int. J. Biol. Macromol. 2020, 143, 991-999. [CrossRef]

171. Preedy, V.R. Essential Oils in Food Preservation, Flavor and Safety; Academic Press: Cambridge, MA, USA, 2015.

172. Durmus, M. The effects of nanoemulsions based on citrus essential oils (orange, mandarin, grapefruit, and lemon) on the shelf life of rainbow trout (Oncorhynchus mykiss) fillets at $4 \pm 2{ }^{\circ} \mathrm{C}$. J. Food Saf. 2019, e12718. [CrossRef]

173. Donsì, F.; Annunziata, M.; Vincensi, M.; Ferrari, G. Design of nanoemulsion-based delivery systems of natural antimicrobials: Effect of the emulsifier. J. Biotechnol. 2012, 159, 342-350. [CrossRef]

174. Kujur, A.; Kiran, S.; Dubey, N.K.; Prakash, B. Microencapsulation of Gaultheria procumbens essential oil using chitosan-cinnamic acid microgel: Improvement of antimicrobial activity, stability and mode of action. LWT 2017, 86, 132-138. [CrossRef]

175. Álvarez-Paino, M.; Muñoz-Bonilla, A.; Fernández-García, M. Antimicrobial polymers in the nano-world. Nanomaterials 2017, 7, 48. [CrossRef]

176. Gupta, A.; Eral, H.B.; Hatton, T.A.; Doyle, P.S. Controlling and predicting droplet size of nanoemulsions: Scaling relations with experimental validation. Soft Matter 2016, 12, 1452-1458. [CrossRef]

177. Prakash, B.; Kujur, A.; Yadav, A.; Kumar, A.; Singh, P.P.; Dubey, N.K. Nanoencapsulation: An efficient technology to boost the antimicrobial potential of plant essential oils in food system. Food Control. 2018, 89, 1-11. [CrossRef]

178. Sánchez-González, L.; Cháfer, M.; Hernández, M.; Chiralt, A.; González-Martínez, C. Antimicrobial activity of polysaccharide films containing essential oils. Food Control 2011, 22, 1302-1310. [CrossRef]

179. Ahmad, M.; Benjakul, S.; Prodpran, T.; Agustini, T.W. Physico-mechanical and antimicrobial properties of gelatin film from the skin of unicorn leatherjacket incorporated with essential oils. Food Hydrocoll. 2012, 28, 189-199. [CrossRef]

180. Aloui, H.; Khwaldia, K.; Licciardello, F.; Mazzaglia, A.; Muratore, G.; Hamdi, M.; Restuccia, C. Efficacy of the combined application of chitosan and Locust Bean Gum with different citrus essential oils to control postharvest spoilage caused by Aspergillus flavus in dates. Int. J. Food Microbiol. 2014, 170, 21-28. [CrossRef]

181. Severino, R.; Ferrari, G.; Vu, K.D.; Donsì, F.; Salmieri, S.; Lacroix, M. Antimicrobial effects of modified chitosan based coating containing nanoemulsion of essential oils, modified atmosphere packaging and gamma irradiation against Escherichia coli O157: H7 and Salmonella typhimurium on green beans. Food Control. 2015, 50, 215-222. [CrossRef]

182. Cháfer, M.; Sánchez-González, L.; González-Martínez, C.; Chiralt, A. Fungal decay and shelf life of oranges coated with chitosan and bergamot, thyme, and tea tree essential oils. J. Food Sci. 2012, 77, E182-E187. [CrossRef]

183. Sessa, M.; Ferrari, G.; Donsì, F. Novel edible coating containing essential oil nanoemulsions to prolong the shelf life of vegetable products. Chem. Eng. Trans. 2015, 43, 55-60.

184. Ramos-García, M.; Bosquez-Molina, E.; Hernández-Romano, J.; Zavala-Padilla, G.; Terrés-Rojas, E.; Alia-Tejacal, I.; Barrera-Necha, L.; Hernández-López, M.; Bautista-Baños, S. Use of chitosan-based edible coatings in combination with other natural compounds, to control Rhizopus stolonifer and Escherichia coli DH5 $\alpha$ in fresh tomatoes. Crop Prot. 2012, 38, 1-6. [CrossRef]

185. Dias, M.V.; De Medeiros, H.S.; Soares, N.D.F.F.; De Melo, N.R.; Borges, S.V.; Carneiro, J.D.D.S.; De Assis Kluge, J.M.T. Development of low-density polyethylene films with lemon aroma. LWT-Food Sci. Technol. 2013, 50, 167-171. [CrossRef]

186. Perdones, Á.; Escriche, I.; Chiralt, A.; Vargas, M. Effect of chitosan-lemon essential oil coatings on volatile profile of strawberries during storage. Food Chem. 2016, 197, 979-986. [CrossRef]

187. Peng, Y.; Li, Y. Combined effects of two kinds of essential oils on physical, mechanical and structural properties of chitosan films. Food Hydrocoll. 2014, 36, 287-293. [CrossRef]

188. Wu, C.; Wang, L.; Hu, Y.; Chen, S.; Liu, D.; Ye, X. Edible coating from citrus essential oil-loaded nanoemulsions: Physicochemical characterization and preservation performance. RSC Adv. 2016, 6, 20892-20900. [CrossRef] 
189. Chouhan, S.; Sharma, K.; Guleria, S. Antimicrobial activity of some essential oils—Present status and future perspectives. Medicines 2017, 4, 58. [CrossRef] [PubMed]

190. Caserta, R.; Teixeira-Silva, N.S.; Granato, L.M.; Dorta, S.O.; Rodrigues, C.M.; Mitre, L.K.; Yochikawa, J.T.H.; Fischer, E.R.; Nascimento, C.A.; Souza-Neto, R.R. Citrus biotechnology: What has been done to improve disease resistance in such an important crop? Biotechnol. Res. Innov. 2020. [CrossRef]

(C) 2020 by the authors. Licensee MDPI, Basel, Switzerland. This article is an open access article distributed under the terms and conditions of the Creative Commons Attribution (CC BY) license (http://creativecommons.org/licenses/by/4.0/). 